\title{
Mixing of shallow and deep groundwater as indicated by the chemistry and age of karstic springs
}

\author{
David J. Toth · Brian G. Katz
}

\section{Publisher's Note: \\ Hydrogeology Journal (2006), pp 827-847 \\ DOI 10.1007/s10040-005-0478-x}

The figures in this article were inadvertently printed in black and white instead of in colour. We apologize very much for this error and provide you here with the corrected printed version.

\begin{abstract}
Large karstic springs in east-central Florida, USA were studied using multi-tracer and geochemical modeling techniques to better understand groundwater flow paths and mixing of shallow and deep groundwater. Spring water types included $\mathrm{Ca}-\mathrm{HCO}_{3}$ (six), $\mathrm{Na}-\mathrm{Cl}$ (four), and mixed (one). The evolution of water chemistry for $\mathrm{Ca}-$ $\mathrm{HCO}_{3}$ spring waters was modeled by reactions of rainwater with soil organic matter, calcite, and dolomite under oxic conditions. The $\mathrm{Na}-\mathrm{Cl}$ and mixed-type springs were modeled by reactions of either rainwater or Upper Floridan aquifer water with soil organic matter, calcite, and dolomite under oxic conditions and mixed with varying proportions of saline Lower Floridan aquifer water, which represented $4-53 \%$ of the total spring discharge. Multiple-tracer data-chlorofluorocarbon CFC-113, tritium $\left({ }^{3} \mathrm{H}\right)$, helium$3\left({ }^{3} \mathrm{He}_{\text {trit }}\right)$, sulfur hexafluoride $\left(\mathrm{SF}_{6}\right)$ - for four $\mathrm{Ca}-\mathrm{HCO}_{3}$ spring waters were consistent with binary mixing curves representing water recharged during 1980 or 1990 mixing
\end{abstract}

Received: 16 June 2005 / Accepted: 1 August 2005

Published online: 29 August 2006

(C) Springer-Verlag 2006

The online version of the original article can be found at http://dx.doi.org/10.1007/s10040-005-0478-x

D. J. Toth $(\bowtie)$

St. Johns River Water Management District,

Palatka, Florida, USA

e-mail: dtoth@srjrwmd.com

Tel.: (386)-329-4242

B. G. Katz

U.S. Geological Survey,

2010 Levy Avenue, Tallahassee, Florida, USA

e-mail: bkatz@usgs.gov with an older (recharged before 1940) tracer-free component. Young-water mixing fractions ranged from 0.3 to 0.7 . Tracer concentration data for two $\mathrm{Na}-\mathrm{Cl}$ spring waters appear to be consistent with binary mixtures of 1990 water with older water recharged in 1965 or 1975 . Nitrate-N concentrations are inversely related to apparent ages of spring waters, which indicated that elevated nitrate- $\mathrm{N}$ concentrations were likely contributed from recent recharge.

Résumé D'importantes sources karstiques du Centre-Est de la Floride aux USA, ont été étudiées par multitraçage et par des techniques de modélisation géochimique, pour mieux comprendre les directions de l'écoulement souterrain et les mélanges entre les eaux souterraines phréatiques et profondes. Les eaux de source sont du type $\mathrm{Ca}-\mathrm{HCO}_{3}$ (six), $\mathrm{Na}-\mathrm{Cl}$ (quatre), et mixte (une). L'évolution de la chimie des eaux du type $\mathrm{Ca}-\mathrm{HCO}_{3}$ a été modélisée par réactions entre l'eau de pluie et la matière organique des sols, la calcite et la dolomite, dans des conditions oxydantes, et par mélange avec des proportions variables de l'eau saline de l'aquifère du Bas-Floridien qui représente 4 à $53 \%$ du débit total de la source.

Les données de multitraçage [chlorofluorocarbone CFC-113, tritium $\left({ }^{3} \mathrm{H}\right)$, hélium-3 $\left({ }^{3} \mathrm{He}_{\text {trit }}\right)$, hexafluorure de sulfure $\left(\mathrm{SF}_{6}\right)$ ] pour quatre eaux $\mathrm{Ca}-\mathrm{HCO}_{3}$ de source, sont cohérentes par rapport aux courbes de mélange binaire représentant la recharge en 1980 ou en 1990, mélangée avec une composante plus ancienne sans traceur (eau d'une recharge antérieure à 1940). Les fractions des eaux jeunes sont comprises entre 0.3 et 0.7. Les concentrations en traceur de deux sources de type $\mathrm{Na}-\mathrm{Cl}$ sont apparues comme cohérentes avec les mélanges binaires des eaux de 1990 et des eaux plus anciennes de 1965 ou 1975. Les concentrations en Nitrates sont inversement liées aux âges apparent des eaux de sources, ce qui indique que les concentrations élevées en Nitrate seraient plutôt dues aux recharges récentes.

Resumen Se estudiaron manantiales kársticos grandes en la parte centro-oriental de Florida, USA utilizando técnicas de modelizado geoquímico y multi-trazadores para un mejor entendimiento de trayectorias de flujo de agua subterránea y la mezcla de agua subterránea profunda y somera. Los tipos de agua de manantial incluyeron $\mathrm{Ca}-$ $\mathrm{HCO}_{3}{ }^{-}$(seis), $\mathrm{Na}-\mathrm{Cl}$ (cuatro), y mezclada (una). Se modelizó la evolución de química de agua para las aguas de 
los manantiales $\mathrm{Ca}-\mathrm{HCO}_{3}{ }^{-}$mediante las reacciones de agua de lluvia con la materia orgánica del suelo, calcita, y dolomita bajo condiciones anóxicas. Los manantiales con $\mathrm{Na}-\mathrm{Cl}$ y mezclados se modelizaron mediante reacciones ya sea de agua de lluvia o agua del acuífero Floridano Superior con materia orgánica del suelo, calcita, y dolomita bajo condiciones anóxicas y mezclando con distintas proporciones de agua salada del acuífero Floridano Inferior, lo cual representó entre 4 y $53 \%$ de la descarga total de los manantiales. Los datos de trazadores múltiples [clorofluorcarbono CFC-113, tritio $\left({ }^{3} \mathrm{H}\right)$, helio-3 $\left({ }^{3} \mathrm{He}_{\text {trit }}\right)$, hexafluoruro de azufre $\left(\mathrm{SF}_{6}\right)$ ] para cuatro manantiales $\mathrm{Ca}-$ $\mathrm{HCO}_{3}{ }^{-}$fueron consistentes con curvas binarias de mezclado que representan agua recargada durante 1980 o 1990 que se mezcló con un componente más viejo libre de trazadores (recargado antes de 1940). Las fracciones mezcladas de agua joven variaron entre 0.3 y 0.7 . Los datos de concentración de trazadores para aguas de dos manantiales $\mathrm{Na}-\mathrm{Cl}$ parecen ser consistentes con las mezclas binarias de agua del año 1990 con aguas más viejas recargadas en 1965 o 1975. las concentraciones de nitrato-N tienen una relación inversa con edades aparentes de aguas de manantiales, lo cual indicó que las concentraciones elevadas en nitrato-N probablemente fueron aportadas por recarga reciente.

Keywords Karst - Groundwater age - Carbonate rocks · Geochemical modeling $\cdot$ Lumped parameter modeling

\section{Introduction}

Spring waters provide valuable information about subsurface hydrogeological and chemical processes, particularly in complex groundwater flow systems where point measurements from wells may not reflect processes that occur over large scales (Manga 2001). Spring-water chemistry represents the temporal, spatial, and vertical integration of water from large parts of an aquifer. Interpreting the subtle differences in the chemical composition of spring waters will enable scientists to better understand groundwater flow and mixing patterns in aquifers.

Spring waters in the St. Johns River Water Management District, Florida, are shown in Fig. 1. Spring waters have shown a steady increase in nitrate- $\mathrm{N}$ concentrations over the past 30 years (Spechler and Halford 2001), as have many other large springs throughout the state (Scott et al. 2002). Protecting water in the Floridan aquifer system (FAS) from further degradation requires information on groundwater flow patterns, transit times of groundwater that issues from springs, and identification of the sources of contamination. Flow systems in karstic aquifer systems are inherently complex. In northern Florida, water enters the FAS as recharge through karst features (e.g., sinkholes), as downward movement through the overlying confining unit, and as upward movement from the Lower Floridan aquifer (LFA) in discharge areas along the St. Johns River. Spring flow results from a combination of groundwater from matrix and conduit convergent flow paths. Large, interconnected conduits allow rapid water movement, discharging young groundwater. Trends in spring discharge over time closely follow trends in rainfall (Knowles et al. 2002), suggesting a rapid response to climatic factors. The presence of elevated levels of nitrate- $\mathrm{N}$ in spring water suggest a substantial contribution to spring discharge from shallow to intermediate flow paths (Toth 1999).

In this study, several environmental tracers (isotopes and trace gases) are used to better understand groundwatermixing patterns and mean transit times of water in the FAS in northeastern Florida. Recent studies have used a combination of environmental tracers to relate nitrate concentrations, historical records of nitrogen loading to groundwater, and transit times of groundwater discharging from springs to better understand the timing of nitrate input to the subsurface and its movement through the groundwater system (Cook and Böhlke 1999; Katz et al. 2001; Böhlke 2002; Katz et al. 2004). Environmental tracer data also have shown that mean transit times of groundwater discharging from springs in karstic systems are highly variable. For example, using tritium $\left({ }^{3} \mathrm{H}\right)$ alone or in combination with data for chlorofluorocarbons (CFCs) and sulfur hexafluoride $\left(\mathrm{SF}_{6}\right)$, mean transit times were estimated to be several years or less for high-elevation springs in Virginia, USA (Plummer et al. 2001), 10-30 years for spring waters in areas where the Upper Floridan aquifer (UFA) is unconfined (Katz et al. 2001), and 20-100 years for karst aquifers discharging to springs in southwestern Turkey (Dincer and Payne 1971). Springs provide a unique opportunity to determine groundwater flow characteristics, thus enabling a better understanding of contaminant movement in complex aquifer systems.

\section{Study area}

The study area includes Marion, Lake, Orange, Seminole, and Volusia Counties in east-central Florida (Fig. 1). The topography ranges from rolling highlands in Orange, Lake, Marion, and western Volusia Counties to flat, swampy lowlands along the St. Johns River floodplain in Seminole, Lake, Marion, and Volusia Counties. Land-surface altitudes in the rolling highlands are generally in the range 30-60 m above mean sea level. In coastal areas and along the St. Johns River, altitudes generally are less than $10 \mathrm{~m}$.

The climate of the study area is humid subtropical, with a mean annual air temperature of $21.7^{\circ} \mathrm{C}$. Rainfall is unevenly distributed throughout the area and varies seasonally. Most of the summer rainfall is a result of local, convective thunderstorms which prevail from June through September. Normal summer rainfall can be substantially augmented by tropical storms and hurricanes that pass through the area. Winters typically are drier than summers. Most of the rainfall in winter results from frontal activity rather than from convective thunderstorms. The average annual rainfall is about $127 \mathrm{~cm}$ over most of the study area (Tibbals 1990).

Hydrogeologic units in the study area include the surficial aquifer system, the intermediate confining unit, and 
Fig. 1 Location map of springs and inferred faults in the top of the Floridan aquifer

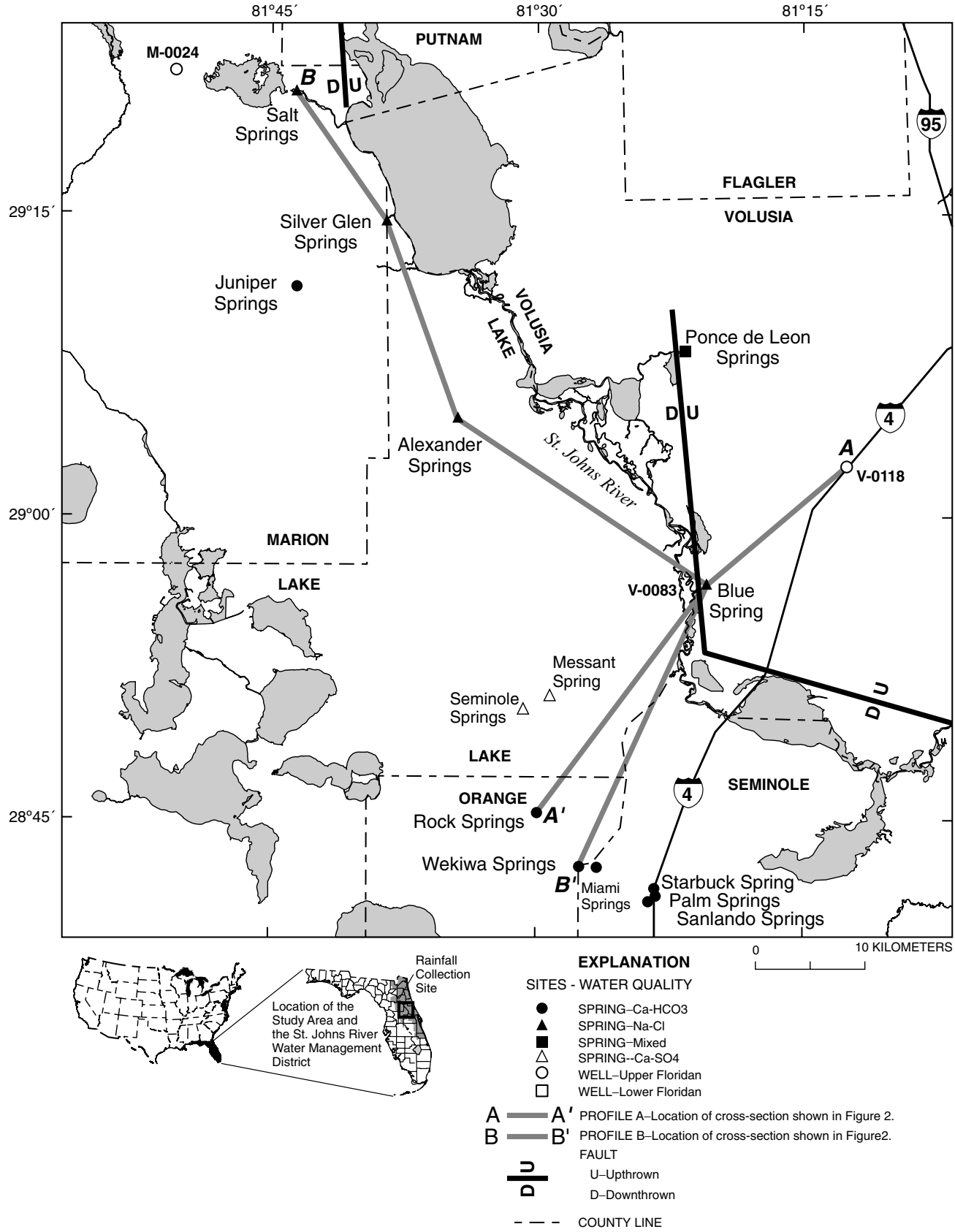

the FAS. The uppermost water-bearing unit is the surficial aquifer system, which is composed of Holocene and Pleistocene sand, clayey sand, clay, and some shell material. Surficial aquifer sediments are either thin or absent where springs are located, as shown in Fig. 2. The intermediate confining unit in the study area consists of undifferentiated deposits of Pliocene sand, silt, and clay as well as Miocene phosphatic sand, silt, clay, limestone, and dolomite of the Hawthorn Group. The clays within the Pliocene sediments and the Hawthorn Group act as confining units that retard the vertical movement of water between the surficial aquifer system and the FAS. Although the thickness of the intermediate confining unit is variable $(0-61 \mathrm{~m})$ throughout much of the study area, it is thin or breached at most sam- pled springs (Fig. 2). More detailed information about the geology and hydrology of these systems can be found in Puri and Vernon (1959), Stringfield (1966), Miller (1982a, 1982b), Miller (1986), Tibbals (1990), and Knowles et al. (2002).

Springs discharge water from the FAS, which lies directly beneath the intermediate confining unit. This aquifer system consists of a thick sequence $(600 \mathrm{~m})$ of limestone and dolomitic limestone. The elevation of the top of the FAS is near land surface at the sampled springs (Fig. 2). The FAS has been divided vertically into three zones on the basis of permeability (Miller 1986). Two relatively high permeability zones are referred to as the Upper and Lower Floridan aquifers. These two zones are separated by a less 
Fig. 2 Cross sections $\mathrm{A}-\mathrm{A}^{\prime}$ and $\mathrm{B}-\mathrm{B}^{\prime}$ showing hydrogeologic framework in study area (refer to Fig. 1 for cross-section locations)
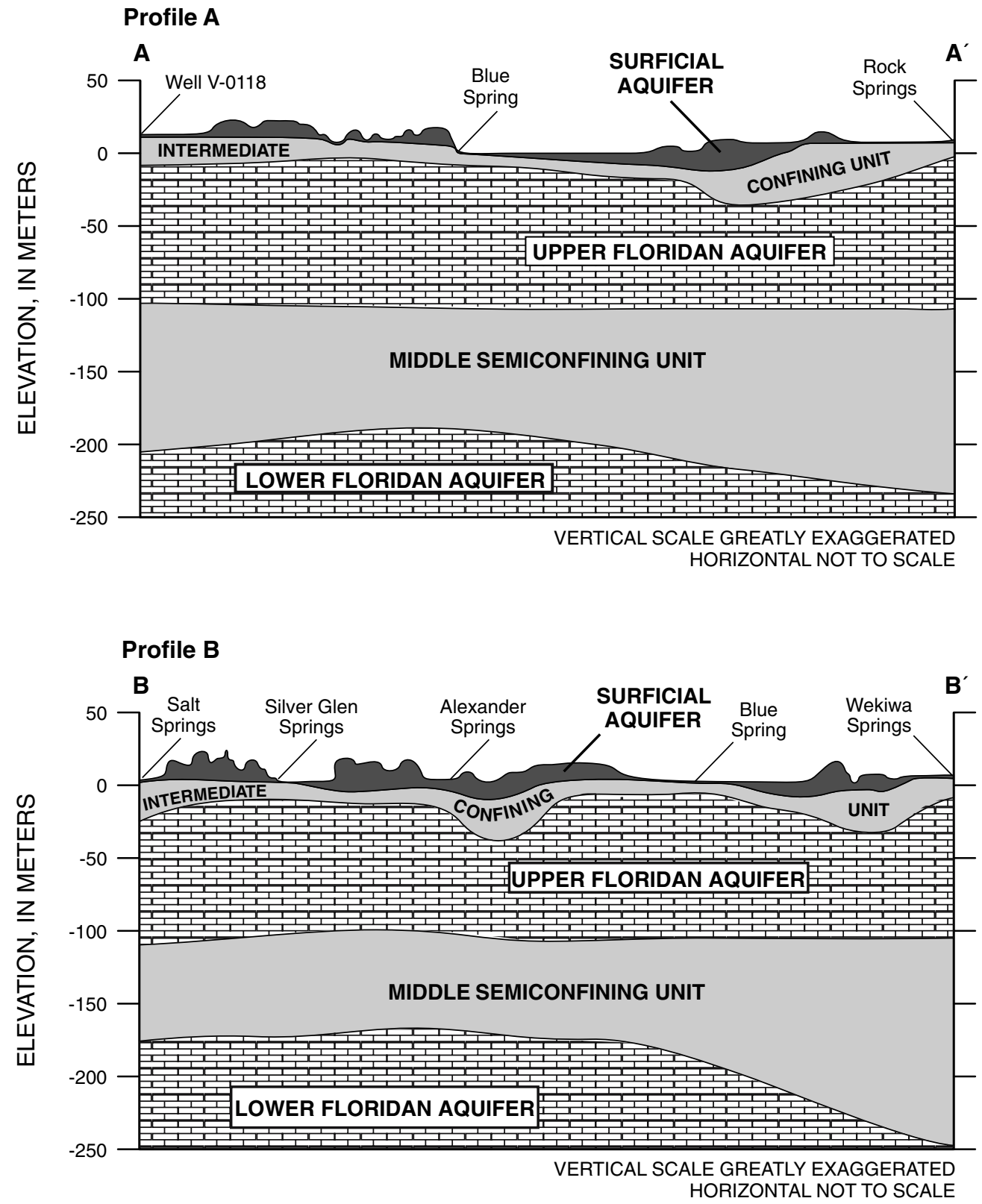

permeable dolomitic limestone referred to as the middle semiconfining unit, which is more than 45 m thick at sampled springs. The Upper Floridan aquifer (UFA) generally consists of the Ocala Limestone and dolomitic limestones of the upper Avon Park Formation. Permeable intervals of the Ocala Limestone are characterized by vuggy to cavernous porosity. The permeability of the upper Avon Park Formation is due primarily to fractures and interconnecting solution cavities. Permeability of both units is enhanced by dissolution along bedding planes, joints, and fractures. The Lower Floridan aquifer (LFA) generally consists of the lower part of the Avon Park Formation, and the Oldsmar Formation (Miller 1986). The depth to the top of the LFA is greater than $92 \mathrm{~m}$ at the sampled springs. The upper surface of the FAS is irregular and paleokarstic (Knowles et al. 2002). Karst topography is present near most springs and generally is characterized by a lack of surface drainage features, and the presence of sinkholes, sinkhole lakes, and numerous springs.

Recharge to the UFA occurs wherever water levels in the surficial aquifer are higher than the potentiometric surface of the underlying UFA. The rate of recharge depends on the difference between water levels in the surficial aquifer and the UFA potentiometric surface, and on the thickness and permeability of the confining unit. Recharge rates are directly proportional to head differences and confining unit permeability, and inversely proportional to confining unit thickness (Tibbals 1990). Relatively high recharge rates $(>20 \mathrm{~cm} / \mathrm{yr}$ ) occur in areas with abundant sinkholes or where the confining unit is thin or breached (Knowles et al. 2002). 
Fig. 3 Potentiometric surface of Upper Floridan aquifer (May 2001), direction of groundwater flow, and spring basin boundaries. Recharge areas and rates are derived from Boniol et al. (1993)

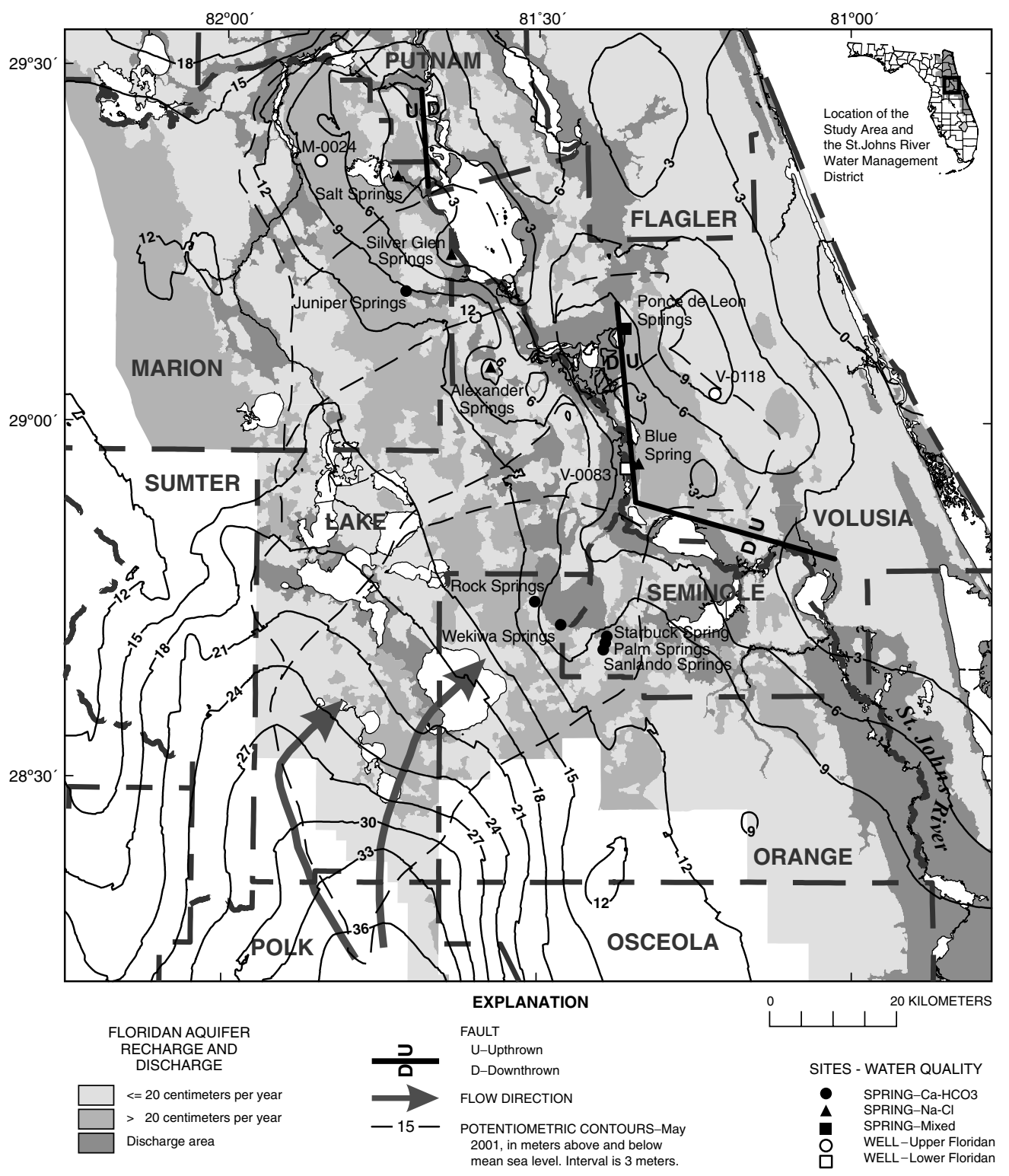

Water levels in the UFA during the sampling period (February-March 2001) are presumed to be similar to the May 2001 potentiometric surface, which represents conditions near the end of the dry season when withdrawals from the aquifer were near maximum and water levels generally were at their seasonal lows, as shown in Fig. 3. Assuming that groundwater flows from areas of high to low potential and perpendicular to potentiometric contours, the regional flow direction is from the southwest toward the northeast in the area southwest of the St. Johns River. East of the St. Johns River, groundwater generally flows from the northeast towards the southwest in delineated spring basins. In the northern part of the study area, flow is from the west or northwest to the east or southeast (O'Reilly and Spechler 2002). Most of the flow comes from high ( $>20 \mathrm{~cm} /$ year) recharge areas. Water generally flows laterally within the UFA; however, vertical upwelling occurs from the LFA in discharge areas near the St. Johns River (Knowles et al.
2002). Leakance of the middle semiconfining unit in these areas is very high due to a deep fracture system that provides good hydraulic connection between the UFA and the LFA (Knowles et al. 2002).

\section{Hydrologic characteristics of sampled springs}

All of the sampled springs are near recharge areas to the Floridan aquifer and many are near areas where the recharge exceeds $20 \mathrm{~cm} /$ year (Fig. 3). Fluctuations of spring water discharge result from seasonal variations in rainfall and recharge (Osburn 2001). Historically, three of the springs have a median discharge greater than $2.8 \mathrm{~m}^{3} / \mathrm{s}$ (which defines first magnitude), seven of the springs have a median discharge range of $0.28-2.8 \mathrm{~m}^{3} / \mathrm{s}$ (second magnitude), and one spring has a median discharge range of $0.028-0.28 \mathrm{~m}^{3} / \mathrm{s}$ (third magnitude) (Rosenau et al. 1977; 
Osburn et al. 2002). The reported median discharge values for the various springs are for different periods of time that all end in 2000. The largest median discharge during these periods was $4.42 \mathrm{~m}^{3} / \mathrm{s}$. However, an assessment of the discharge data presented in Table 1 revealed that drought conditions in the period 1998-2001 resulted in decreased flow at all springs (Osburn et al. 2002). When sampled in February-March 2001, the discharge for the sampled springs was $0.15-2.80 \mathrm{~m}^{3} / \mathrm{s}$, which was $0.03-1.62 \mathrm{~m}^{3} / \mathrm{s}$ lower than historical median discharge values for these springs.

Hydrologic contributing areas for some springs in the study have been delineated by using the MODFLOW particle-tracking program (Pollock 1994) described in previous studies. The modeled contributing area to Alexander Springs covers approximately $200 \mathrm{~km}^{2}$ southwest of the springs, based on average 1998 hydrologic conditions (Knowles et al. 2002). They estimated that a recharge rate of $45 \mathrm{~cm} /$ year was needed to supply the springflow of $2.9 \mathrm{~m}^{3} / \mathrm{s}$. Contributing areas that account for $95 \%$ of the total discharge from Rock, Wekiwa, Palm, Sanlando, Starbuck, Miami, Messant, and Seminole Springs (see Fig. 1) were estimated to cover approximately $830 \mathrm{~km}^{2}$ extending into northwestern Orange, eastern Lake, and southwestern Seminole Counties (Murray and Halford 1996).

\section{Methods}

\section{Sample collection and analysis}

Samples of water from the first magnitude springs were collected by lowering a positive displacement dual-piston pump head about 5-15 $\mathrm{m}$ into the spring vent. Water was pumped at approximately $0.06 \mathrm{~L} / \mathrm{s}$ through $0.63-\mathrm{cm}$ diameter copper (refrigeration-grade) tubing. Sampling methodology varied somewhat depending on accessibility to the spring and site characteristics. Specific conductance, $\mathrm{pH}$, dissolved oxygen, and temperature were measured in situ by using either a closed flow-through chamber or a multiprobe unit that was lowered directly into the spring vent. Field-sampling protocols and methods for chemical and isotopic analyses are described in detail by Katz et al. (1999) and Toth (1999).

\section{Dating spring waters}

To better understand the transit time of groundwater exiting from springs, water samples were analyzed for the transient environmental tracers, the CFCs trichlorofluoromethane $\left(\mathrm{CCl}_{3} \mathrm{~F}\right)$, dichlorodifluoromethane $\left(\mathrm{CCl}_{2} \mathrm{~F}_{2}\right)$, and trichlorotrifluoroethane $\left(\mathrm{C}_{2} \mathrm{Cl}_{3} \mathrm{~F}_{3}\right),{ }^{3} \mathrm{H}$ and its radioactive decay product $\left({ }^{3} \mathrm{He}_{\text {trit }}\right)$, and $\mathrm{SF}_{6}$. Anthropogenic activities such as industrial processes and atmospheric testing of thermonuclear devices, have released $\mathrm{CFCs}, \mathrm{SF}_{6}$, and ${ }^{3} \mathrm{H}$ into the atmosphere in low but measurable concentrations. Precipitation that incorporates $\mathrm{CFCs}$, and $\mathrm{SF}_{6}$, and ${ }^{3} \mathrm{H}$ from the atmosphere infiltrates into the ground and carries a particular chemical or isotopic signature related to atmospheric conditions at the time of recharge to the UFA. The CFC, ${ }^{3} \mathrm{H} /{ }^{3} \mathrm{He}_{\text {trit }}$, and $\mathrm{SF}_{6}$ dating methods assume that gas exchange between the unsaturated zone and air is fast, but that shallow groundwater remains closed to gas exchange after recharge (Schlosser et al. 1989; Plummer and Busenberg 1999; Busenberg and Plummer 2000).

\section{Tritium and tritium/helium-3}

The continued decrease and low concentrations of ${ }^{3} \mathrm{H}$ in rainfall in the southeastern US have resulted in limited use of the ${ }^{3} \mathrm{H}$ method for age dating groundwaters recharged during the past 2-3 decades. However, by measuring tritiogenic helium-3 $\left({ }^{3} \mathrm{He}_{\text {trit }}\right)$, the stable daughter product of ${ }^{3} \mathrm{H}$ decay that has accumulated in groundwater systems, the dating range and precision can be enhanced (Plummer et al. 1998; Cook and Böhlke 1999). Combined measurements of ${ }^{3} \mathrm{H}$ and its daughter product of radioactive decay, ${ }^{3} \mathrm{He}_{\text {trit }}$, define a relatively stable tracer of the initial ${ }^{3} \mathrm{H}$ input to groundwater, which can be used to calculate the ${ }^{3} \mathrm{H} /{ }^{3} \mathrm{He}_{\text {trit }}$ age from a single water sample (Schlosser et al. 1988, 1989; Solomon and Sudicky 1991). The ${ }^{3} \mathrm{H} /{ }^{3} \mathrm{He}_{\text {trit }}$ ratio yields the following equation for the piston-flow assumption in which the apparent age ( $T$, years) can be expressed as (Torgersen et al. 1979)

$T=1 / \lambda_{T}\left[\ln \left(1+{ }^{3} \mathrm{He}_{\text {trit }} /{ }^{3} \mathrm{H}\right)\right]$,

where $\lambda_{T}$ is the radioactive decay constant for ${ }^{3} \mathrm{H},{ }^{3} \mathrm{H}$ is the concentration in tritium units (TU), and ${ }^{3} \mathrm{He}_{\text {trit }}$ is the tritiogenic ${ }^{3} \mathrm{He}$ content (TU). One TU is equal to one ${ }^{3} \mathrm{H}$ atom in $10^{18}$ hydrogen atoms. It also is equivalent to 3.2 picocuries per liter of water. A He-isotope mass balance is used to calculate the amount of tritiogenic and non-tritiogenic ${ }^{3} \mathrm{He}$ in the sample. Non-tritiogenic ${ }^{3} \mathrm{He}$ (which generally is negligible in a shallow aquifer with local recharge) is corrected for by using measured concentrations of ${ }^{4} \mathrm{He}$ and neon $(\mathrm{Ne})$ in the water sample and assuming solubility equilibrium with air at the water temperature measured during sampling (Schlosser et al. 1988, 1989). It is assumed that ${ }^{3} \mathrm{H}$ and ${ }^{3} \mathrm{He}_{\text {trit }}$ concentrations in groundwater are not affected by contamination, sorption, and microbial degradation processes that can alter the concentrations of other transient tracers such as CFCs (Plummer et al. 1998). The distribution of ${ }^{3} \mathrm{H}$ and ${ }^{3} \mathrm{He}_{\text {trit }}$ can, however, be affected by hydrodynamic dispersion and mixing different age waters (Solomon and Sudicky 1991; Reilly et al. 1994).

Information about groundwater transit times can be obtained (and illustrated in Fig. 4a) by comparing measured ${ }^{3} \mathrm{H}$ concentrations in groundwater with the long-term ${ }^{3} \mathrm{H}$ input function of rainfall measured at the International Atomic Energy Agency (IAEA) precipitation monitoring station in Ocala, Florida (Michel 1989), which is $16 \mathrm{~km}$ west of the study area. Atmospheric weapons testing beginning in the early 1950 s increased ${ }^{3} \mathrm{H}$ concentrations in rainfall in this area to a maximum of several hundred TU during the mid-1960s, followed by a nearly logarithmic decrease in concentrations to the present. Analyti- 


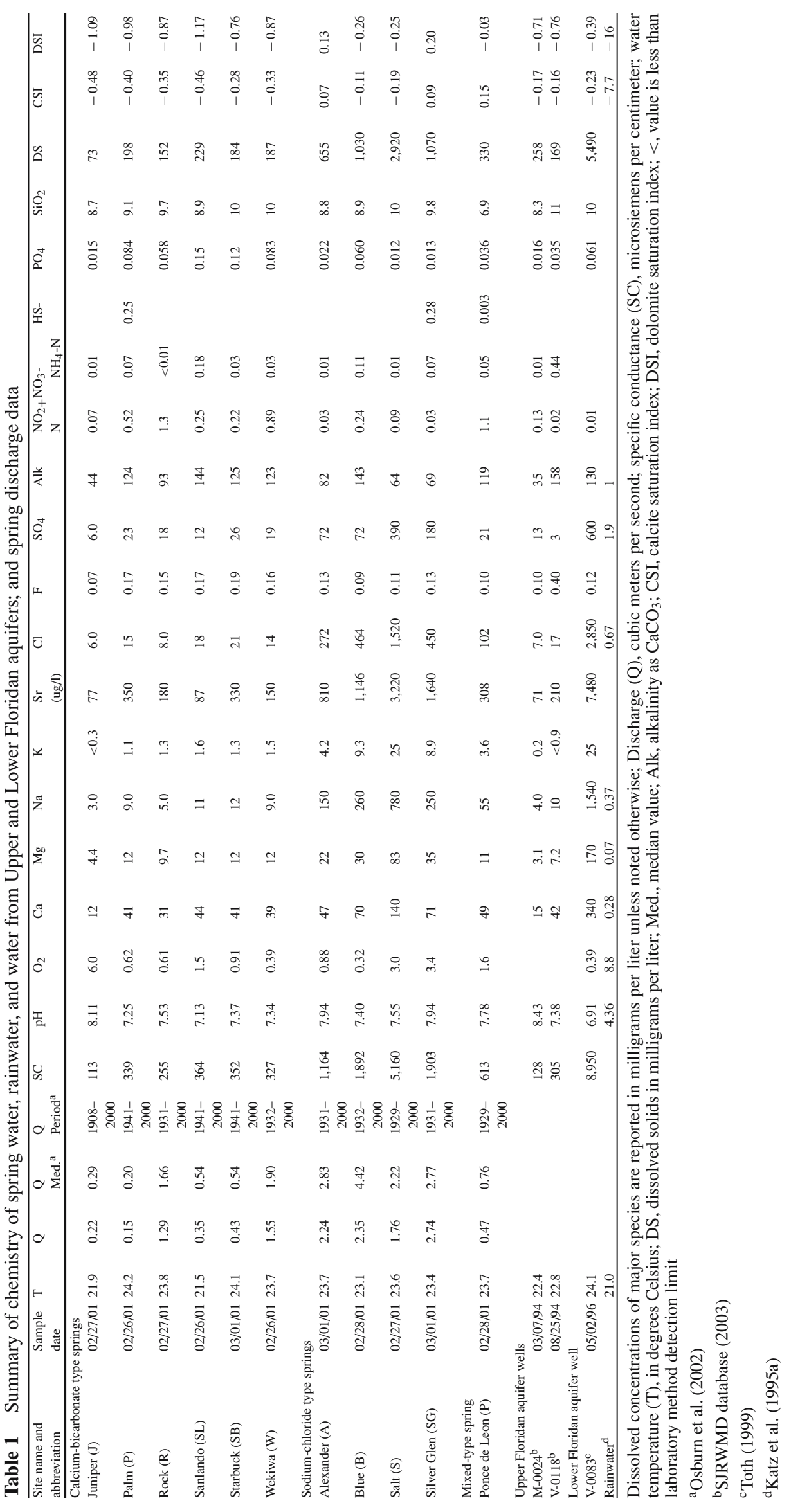



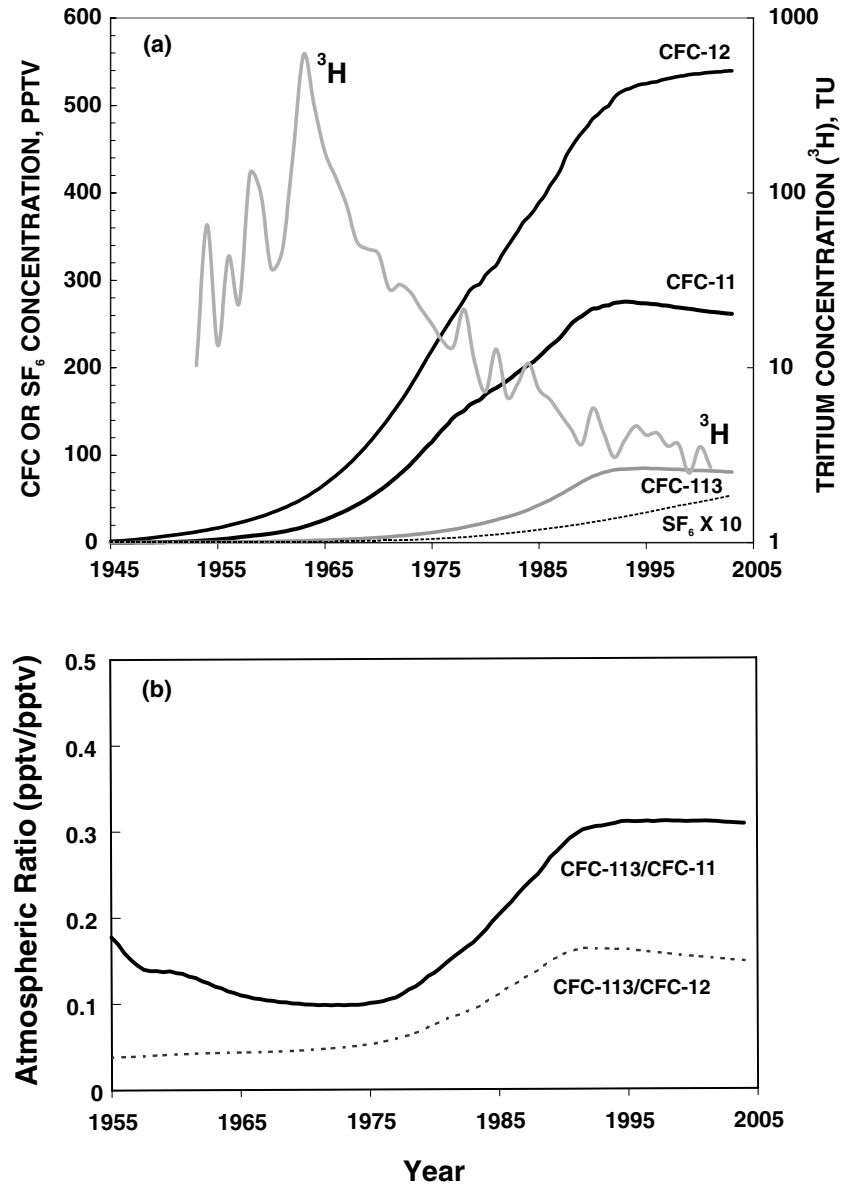

Fig. 4 a Atmospheric input curves for $\mathrm{CFCs}, \mathrm{SF}_{6}$, and tritium in rainfall; b Atmospheric ratios of CFC-113/CFC-12 and CFC113/CFC-11

cal uncertainty $(1 \sigma)$ for ${ }^{3} \mathrm{H}$ using the low-level counting procedure is approximately $\pm 0.15-0.30 \mathrm{TU}$ (Ludin et al. 1998).

Water samples for the determination of ${ }^{3} \mathrm{H} /{ }^{3} \mathrm{He}_{\text {trit }},{ }^{4} \mathrm{He}$, and $\mathrm{Ne}$ were collected in pinched-off copper tubes $(10 \mathrm{~mm}$ diameter, $80 \mathrm{~cm}$ length, approximately $40 \mathrm{ml}$ volume) while applying back pressure to prevent formation of gas bubbles. These samples were analyzed at the Noble Gas Laboratory of Lamont-Doherty Earth Observatory by using quantitative gas extraction followed by mass spectrometric techniques (Schlosser et al. 1989; Ludin et al. 1998).

\section{Chlorofluorocarbons and $\mathrm{SF}_{6}$}

The $\mathrm{CFC}$ and $\mathrm{SF}_{6}$ age-dating techniques rely on the stability of these halogenated hydrocarbon and sulfur compounds in the hydrosphere, which has led to their effective use as tracers to date groundwater recharged during the past 50 years (Plummer and Busenberg 1999; Busenberg and Plummer 2000). These techniques presume that $\mathrm{CFC}$ and $\mathrm{SF}_{6}$ concentrations in the aquifer have not been altered by biological, geochemical, or hydrologic processes.
Apparent ages for CFCs and $\mathrm{SF}_{6}$ are estimated based on the equilibrium partitioning between recharging groundwater and the partial pressures of trichlorofluoromethane (CFC-11), dichlorodifluoromethane (CFC-12), trichlorotrifluoroethane (CFC-113), and $\mathrm{SF}_{6}$ in the troposphere or soil atmosphere (See Fig. 4a). Concentrations of CFCs and $\mathrm{SF}_{6}$ in groundwater are functions of the atmospheric partial pressures and the temperature at the base of the unsaturated zone during recharge. The recharge temperature and the quantity of dissolved excess air (Heaton and Vogel 1981) are determined from gas-chromatography analyses of $\mathrm{N}_{2}$ and argon (Ar) in the headspace of water samples collected in the field (Busenberg et al. 1993). An apparent age of the sampled water is determined from a comparison of the partial pressure of each CFC compound and $\mathrm{SF}_{6}$ in the sample, calculated from their measured concentrations using solubility data for each compound, with the record of atmospheric partial pressures over North America at different times (Fig. 4a). Input functions for $\mathrm{CFCs}$ and $\mathrm{SF}_{6}$ were obtained from their atmospheric input curves, and assuming a ratio of summer-to-winter infiltration coefficient of 1.0. Concentrations of the three CFC compounds and $\mathrm{SF}_{6}$ ideally provide four independent ages which can be used as a cross-check on the sampling and analytical methods. Additional age information, illustrated in Fig. 4b, can be obtained from ratios of atmospheric CFC compounds (e.g., CFC-113/CFC-12 and CFC$113 /$ CFC-11) that have varied over time (Plummer and Busenberg 1999). Discrepancies between ages obtained from CFC ratios and individual compounds provide important information about water mixtures. Analytical procedures for CFCs and $\mathrm{SF}_{6}$ sampling are described by Busenberg and Plummer (1992) and Busenberg and Plummer (2000).

\section{Carbon-14}

Springs were sampled during a previous study (1995-1996) for carbon-14 $\left({ }^{14} \mathrm{C}\right)$ content to estimate age (Toth 1999). Dating groundwater is based on the radioactive decay of ${ }^{14} \mathrm{C}$, which enters the aquifer through recharge of rainfall and begins to decay once groundwater is no longer exposed to atmospheric carbon dioxide. Because various geochemical reactions can alter the ${ }^{14} \mathrm{C}$ content of dissolved inorganic carbon, the computer program, NETPATH (Plummer et al. 1994), is used in this paper to estimate the ${ }^{14} \mathrm{C}$ age of these spring waters, using the measured chemical composition, delta carbon- 13 content of dissolved inorganic carbon $\left(\delta^{13} \mathrm{C}_{\text {DIC }}\right)$, and several well-known adjustment models to obtain estimates of the initial ${ }^{14} \mathrm{C}$. Each adjustment model uses the initial ${ }^{14} \mathrm{C}$ to compute the ${ }^{14} \mathrm{C}$ expected in the final (spring) water as if there were no radioactive decay. The adjusted no-decay ${ }^{14} \mathrm{C}$ activity is then used with the measured ${ }^{14} \mathrm{C}$ activity, expressed as percent modern carbon $(\mathrm{pmc})$ to compute the age. The ${ }^{14} \mathrm{C}$ age is calculated using a half-life of 5,730 years (Plummer et al. 1994). ${ }^{14} \mathrm{C}$ and ${ }^{13} \mathrm{C}$ concentrations were analyzed at the University of Waterloo, in Ottawa, Canada (Toth 1999). 


\section{Estimating transit times of groundwater using lumped parameter models}

Although analytical procedures are capable of determining extremely low concentrations of tracers in groundwater, the subsequent interpretation of groundwater transit time (residence time) in complex aquifer systems still is fraught with a high degree of uncertainty. In many previous studies where $\mathrm{CFCs}, \mathrm{SF}_{6}$, and ${ }^{3} \mathrm{H} /{ }^{3} \mathrm{He}_{\text {trit }}$ have been used to date groundwater, flow systems were relatively well- characterized and water samples typically were collected from discrete depth intervals. Extending tracer age-dating techniques to groundwater from large springs in complex karstic systems requires an analysis of several possible groundwater flow scenarios that influence the concentrations of these tracers in spring waters.

Lumped parameter models are used in this study to estimate the mean transit time of groundwater discharging from large springs. These models treat the aquifer system as a homogeneous compartment in which tracer input concentrations are converted to tracer output concentrations according to the system response function used and how the flow system is described (Zuber 1986; Maloszewski and Zuber 1982; Ozyurt and Bayari 2003). No detailed information, however, is needed regarding the flow system such as boundary conditions, porosity, hydraulic conductivity, which are necessary for numerical models based on Darcy's Law. Lumped parameter models assume a steady-state flow system and assume that the selected tracers behave like a water molecule. Although this assumption typically is valid for tritium, which is part of the water molecule, the gas tracers (CFCs and $\mathrm{SF}_{6}$ ) may show significant variation due to sorption and other biogeochemical processes (Cook et al. 1995; Plummer and Busenberg 1999). The mean transit time of groundwater discharging from a spring represents the time elapsed since recharge and isolation of the tracer from the modern atmosphere. Flow system characteristics are represented by two end member models, piston flow, and exponential flow. The piston-flow model (PFM) assumes that after a tracer is isolated from the atmosphere (at the time of groundwater recharge), it becomes incorporated in a parcel of water that moves from the recharge area with the mean velocity of groundwater. All flow lines are assumed to have similar velocities and hydrodynamic dispersion and molecular diffusion of the tracer are assumed to be negligible.

The exponential flow model (EM) represents an aquifer system in which the mean transit time or age of spring water is exponentially distributed. Spring flow is composed of recharge from all past years; however, their contributions to spring discharge decrease exponentially from the most recent recharge to that which has occurred in the very distant past. Groundwater moves slowly through very small openings in the carbonate matrix, fractures, or fissures, and much more rapidly through large conduits or caverns, many of which have been mapped by cave divers for Wekiwa, Blue, Silver Glen, and Alexander Springs. Dye tracer studies at Rock Springs have indicated that flow through conduits is rapid, in the order of 3,000-23,000 m/day (W. Belleville, St. Johns River Water Management District, 2003, personal communication).

Other lumped parameter models that account for mixing include combined exponential and piston flow (EPM), and dispersion (DM). The EM, EPM, and DM have the same fitted parameter (mean transit time or mean-tracer age), and age distributions that are obtained from a response function (Maloszewski and Zuber 1996). By fitting measured tracer concentrations to modeled output curves, the response function accounts for the distribution of ages at a sampling site (spring or well) (Zuber et al. 2001). The EPM and DM each have an additional fitting parameter: the EPM contains $(\eta)$, a ratio of the total volume to the volume with the exponential distribution of ages; the DM contains $P_{\mathrm{D}}$, an apparent dispersivity of the aquifer system (Maloszewski and Zuber 1996). This term, which is unrelated to the actual dispersivity, represents the variance of the distribution of flow lines with different ages that converge at the sampled spring or well. The computer program FLOWPC (Maloszewski and Zuber 1996) is used to calculate theoretical curves for the different lumped parameter models using atmospheric input data for the various tracers (Fig. 4a).

In addition to the above models, simple binary mixing models (BM) are used to evaluate mixing scenarios involving relatively young water (recharged within the past 7 years) from the shallow part of the flow system with older water (decades) presumably from the deeper part of the UFA (Katz et al. 2001). In principle, both end members of a binary mixture can be of any age, but the calculation is greatly simplified if it is assumed that one or both end members is either "young" (recharged after 1995 when $\mathrm{CFC}$ or $\mathrm{SF}_{6}$ concentrations in the atmosphere have been relatively constant) or "old" (recharged before 1940 with undetectable $\mathrm{CFC}$ or $\mathrm{SF}_{6}$ concentrations).

\section{Results and discussion}

\section{Chemical and isotopic composition of springs}

Spring-water chemistry is highly variable throughout the study area. Chloride concentrations ranged from $6 \mathrm{mg} / \mathrm{L}$ at Juniper Springs to $1,518 \mathrm{mg} / \mathrm{L}$ at Salt Springs and are summarized in Table 1. Similarly, concentrations of sulfate and dissolved solids ranged from 6 and $73 \mathrm{mg} / \mathrm{L}$, respectively, at Juniper Spring, and to 387 and 2,920 mg/L, respectively, at Salt Springs. Six springs (Wekiwa, Rock, Palm, Sanlando, Starbuck, and Juniper) had $\mathrm{Ca}-\mathrm{HCO}_{3}$ water; four springs (Salt, Silver Glen, Alexander, and Blue) had sodium chloride $(\mathrm{Na}-\mathrm{Cl})$ type water; and one spring (Ponce de Leon) was a mixed type (calcium-bicarbonate $\left(\mathrm{Ca}-\mathrm{HCO}_{3}\right)$ and $\mathrm{Na}-\mathrm{Cl}$ ) (Fig. 1). Ca- $\mathrm{HCO}_{3}$ spring waters most likely represent groundwater flow along relatively short, lateral flow paths that originate in high-rate recharge areas (Murray and Halford 1996). $\mathrm{Na}-\mathrm{Cl}$ spring waters likely result from the mixing of freshwater with entrapped relict seawater or from 
the upwelling of deeper brackish water through fractures or faults.

Dissolved oxygen $\left(\mathrm{O}_{2}\right)$ concentrations were highest $(6.0 \mathrm{mg} / \mathrm{L})$ at Juniper Springs and lowest $(0.32 \mathrm{mg} / \mathrm{l})$ at Blue Springs (Table 1). Oxygen concentrations in spring waters can be indicative of the young water fraction, and high concentrations may indicate a large young-water component. Statistically significant correlations were found between the age of spring waters and $\mathrm{O}_{2}$ concentrations in the Suwannee River Basin of northern Florida (Katz et al. 1999).

Nitrate-N (nitrate plus nitrite as $\mathrm{N}$ ) concentrations were greater than $0.20 \mathrm{mg} / \mathrm{L}$ in seven spring waters. The highest concentration, $1.29 \mathrm{mg} / \mathrm{L}$, occurred at Rock Springs. Other "elevated" concentrations above background levels (Katz 1992) were found at Ponce de Leon Spring, Wekiwa Springs, and Palm Springs. The lowest nitrate-N concentrations were found in waters from Juniper, Salt, Alexander, and Silver Glen Springs, which are located in the Ocala National Forest.

Elevated nitrate- $\mathrm{N}$ concentrations in spring water suggest that water from the shallow part of the flow system contributes substantial flow to the spring discharge, since nitrate sources occur at or near the ground surface. Anecdotal evidence and field observations suggest nitrate-N levels of greater than $1 \mathrm{mg} / \mathrm{L}$ cause a significant shift in the balance of spring ecological communities, leading to intensified degradation of biological systems (Florida Springs Task Force 2000). The major cause of concern is algal growth and eutrophication, both of which can cause the clarity of spring water to diminish.

\section{Geochemical modeling of spring water chemistry}

The evolution of spring water chemistry was modeled by using NETPATH (Plummer et al. 1994). Initial waters consisted of rainfall, UFA recharge water, and LFA water, and the various spring waters were considered the final waters. Water-quality data from two UFA wells (M-0024 and V0118), a well completed in the middle semiconfining unit (V-0083), and rainfall are used to represent deep and shallow end-member waters in geochemical models. The two UFA wells are located in recharge areas for the aquifer and contain $\mathrm{Ca}-\mathrm{HCO}_{3}$ type water. The middle semiconfining unit well is in a discharge area for the FAS where vertical upwelling occurs and contains $\mathrm{Na}-\mathrm{Cl}$ type water (Toth 1999); this water chemistry is assumed to represent that of the LFA. Rainfall composition is from a station in northwest Putnam County, Florida, several $\mathrm{km}$ west of the study area (Katz et al. 1995a).

Several stable and radioactive isotope values measured previously for water discharging from all 11 sampled springs and from well V-0083 (Toth 1999) are used in the models described below. The $\delta^{13} \mathrm{C}_{\text {DIC }}$ values ranged from -7.7 to $-10.9 \%$ (Toth 1999 ), and ${ }^{14} \mathrm{C}$ content ranged from 6.7 to 57 pmc. $\delta^{13} \mathrm{C}_{\text {DIC }}$ and ${ }^{14} \mathrm{C}$ in UFA wells in recharge areas are assumed to be $-12.0 \%$ and $50 \mathrm{pmc}$, respectively (Deines 1980; Plummer and Sprinkle 2001; Toth
1995). A value of $-7.0 \%$ was used for $\delta^{13} C_{\text {DIC }}$ in rainfall (Katz et al. 1995b). ${ }^{14} \mathrm{C}$ in rainfall was assumed to be $100 \mathrm{pmc}$. Initial $\delta^{13} \mathrm{C}_{\mathrm{DIC}}$ values for organic matter, calcite, and dolomite varied within ranges reported in the literature (Plummer et al. 1994; Plummer and Sprinkle 2001; Phelps 2001). Initial $\delta^{13} C_{\text {DIC }}$ for organic matter ranged between -20 and $-24 \%$ o. Initial $\delta^{13} \mathrm{C}_{\text {DIC }}$ for calcite and dolomite varied between $\pm 2 \%$.

Geochemical reactions and associated mass transfer coefficients are presented in Table 2 for springs grouped by water type. The reactions that produced the best agreement between calculated and measured $\delta^{13} \mathrm{C}_{\text {DIC }}$ for respective spring-water samples were assumed to represent the geochemical reactions that occur within each spring basin. For $\mathrm{Ca}-\mathrm{HCO}_{3}$ type springs (Table 2), differences between observed and calculated values for $\delta^{13} \mathrm{C}_{\text {DIC }}$ were less than $-1.2 \%$. For $\mathrm{Na}-\mathrm{Cl}$ type springs, this difference is less than $-2.4 \%$. The largest difference between observed and calculated values for $\delta^{13} \mathrm{C}_{\text {DIC }}$ was $3.5 \%$, which occurred for the mixed-type spring (Table $2)$. These differences are justified, considering the uncertainty in the $\delta^{13} C_{\text {DIC }}$ values for organic matter, calcite, and dolmite.

For reactions 2, 3, 4, and 5 in Table 2, LFA water mixes with an end member having either the composition of rainwater or UFA water. LFA water is the source of chloride for $\mathrm{Na}-\mathrm{Cl}$ and mixed-type spring waters. Many of these springs are near the St. Johns River where vertical upconing of LFA water occurs (Knowles et al. 2002). Calculated amounts of LFA water ranged from $4 \%$ (Ponce de Leon Spring) to 53\% (Salt Springs) of the total spring discharge (Table 2). The amount of LFA water was determined by a mass balance calculation and is based on the chloride concentrations in each end member and the spring.

The fraction of LFA water mixing with UFA water estimated from the water chemistry for the above springs cannot be compared directly with estimates based on numerical groundwater flow modeling because of the structure of the flow models. In the flow models, the LFA is either inactive (no upward movement of water from the LFA) or is specified as a general head boundary directly beneath the spring (upward flow based on water mass balance but not taking water chemistry into consideration).

\section{Apparent ages of spring waters}

Apparent ages of spring waters were estimated by using a piston-flow assumption along with measured concentration data for ${ }^{3} \mathrm{H} /{ }^{3} \mathrm{He}_{\text {trit }}, \mathrm{CFCs}$, and $\mathrm{SF}_{6}$. The piston flow model is applied in this study to investigate the occurrence of water mixing. If mixing is occurring, the piston flow model should yield inconsistent apparent ages for the different tracers. Concentrations of CFC-11, CFC-12, CFC-113, SF 6 , and selected tracer ratios (CFC-11/CFC-12, CFC-113/CFC-12, and $\mathrm{SF}_{6} / \mathrm{CFC}-113$ ) in water samples generally did not yield concordant ages based on atmospheric equilibration data. These data are presented in Tables 3 and 4, and illustrated in Fig. 5. Most springs have concentrations of CFCs that are within the range expected for air-saturated waters that 
Table 2 Reactions and mass transfer coefficients of representative mixtures for the chemical evolution of spring waters

\begin{tabular}{|c|c|c|c|c|c|c|c|c|c|c|c|}
\hline \multirow{2}{*}{$\begin{array}{l}\text { End } \\
\text { member/phase }\end{array}$} & \multicolumn{6}{|c|}{ Calcium-Bicarbonate Type Springs } & \multicolumn{4}{|c|}{ Sodium-Chloride Type Springs } & \multirow{2}{*}{$\begin{array}{l}\text { Mixed-type spring } \\
\text { Ponce de Leon }\end{array}$} \\
\hline & Juniper & Palm & Rock & Sanlando & Starbuck & Wekiwa & Alexander & Blue & Salt & Silver Glen & \\
\hline$\overline{\mathrm{RW}}$ & 1.0 & 1.0 & 1.0 & 1.0 & 1.0 & 1.0 & 0.91 & - & - & 0.84 & 0.96 \\
\hline UFW & - & - & - & - & - & - & - & 0.84 & 0.47 & - & - \\
\hline LFW & - & - & - & - & - & - & 0.09 & 0.16 & 0.53 & 0.16 & 0.04 \\
\hline Calcite & 0.11 & 0.52 & 0.37 & 0.59 & 0.53 & 0.50 & 0.16 & -0.46 & - & 0.13 & 0.74 \\
\hline Dolomite & 0.18 & 0.50 & 0.40 & 0.50 & 0.49 & 0.47 & 0.20 & & - & 0.31 & 0.18 \\
\hline $\mathrm{CO}_{2}$ gas & 0.31 & 0.97 & 0.53 & 1.49 & 0.95 & 0.97 & 0.55 & - & - & 0.13 & 1.00 \\
\hline $\mathrm{CH}_{2} \mathrm{O}$ & 0.09 & 0.26 & 0.26 & 0.23 & 0.25 & 0.26 & 0.22 & - & - & - & 0.22 \\
\hline $\mathrm{O}_{2}$ gas & - & - & - & - & - & - & - & - & - & -0.13 & - \\
\hline$\delta^{13} \mathrm{C}$ (obs) & -9.5 & -10.9 & -9.1 & -10.5 & -10.5 & -10.1 & -9.5 & -10.1 & -8.3 & -7.7 & -8.0 \\
\hline$\delta^{13} \mathrm{C}$ (calc) & -9.9 & -11.1 & -9.1 & -11.7 & -10.8 & -10.2 & -11.9 & -11.6 & -8.7 & -6.3 & -11.5 \\
\hline$\delta^{13} \mathrm{C} \mathrm{CH}_{2} \mathrm{O}$ & -20 & -24 & -22 & -20 & -24 & -22 & -20 & - & - & - & -20 \\
\hline$\delta^{13} \mathrm{C} \mathrm{CO}_{2}$ & -25 & -25 & -25 & -25 & -25 & -25 & -25 & - & - & -25 & -25 \\
\hline$\delta^{13} \mathrm{C}$ calcite & 2.0 & 0.0 & 1.0 & 2.0 & 1.0 & 2.0 & 2.0 & 0.0 & - & -2.0 & 2.0 \\
\hline$\delta^{13} \mathrm{C}$ dolomite & 2.0 & 0.0 & 1.0 & 2.0 & 0.0 & 2.0 & 2.0 & - & - & -2.0 & 2.0 \\
\hline
\end{tabular}

End members in models included rainwater (RW), Upper Floridan water (UFW, wells V-0118 or M-0024), Lower Floridan water (LFW, well V-0083); phases included calcite (cal), dolomite (dol), $\mathrm{CO}_{2}, \mathrm{CH}_{2} \mathrm{O}$ (organic matter), and $\mathrm{O}_{2}$, model constraints included Ca, $\mathrm{Mg}$, and $\mathrm{C}$; mixing based on CI; units are mmol $/ \mathrm{kg}, \delta^{13} \mathrm{C}$ values are per mil; obs, observed value from Toth (1999); calc, value calculated from mass-balance model; positive values indicate dissolution of the phases and negative values signify precipitation of the phases or ingassing and outgassing in the case of gases; - denotes end member or phase not included in model

Reactions:

Calcium-bicarbonate type springs:

$\mathrm{RW}+\mathrm{CH}_{2} \mathrm{O}+$ Calcite + Dolomite $+\mathrm{O}_{2}=\mathrm{Ca}-\mathrm{HCO}_{3}$ Spring water (1)

Sodium-chloride type springs:

$\mathrm{RW}+\mathrm{LFA}+\mathrm{CH}_{2} \mathrm{O}+$ Calcite + Dolomite $+\mathrm{O}_{2}=\mathrm{Na}-\mathrm{Cl}$ Spring water $(2)$

UFW (V-0118) + LFA + Calcite $=$ Blue Spring water (3)

UFW (M-0024) + LFA = Salt Spring water (4)

Mixed-type spring:

$\mathrm{RW}+\mathrm{LFA}+\mathrm{CH}_{2} \mathrm{O}+$ Calcite + Dolomite $+\mathrm{O}_{2}=$ Ponce de Leon water (5)

are less than 40 years old; however, apparent (piston-flow) ages are different for the three CFC compounds (Table $3)$. Higher CFC-11 apparent ages likely result from microbial degradation in the aquifer system under reducing conditions (Plummer and Busenberg 1999). Methane was detected in waters from Blue, Palm, and Sanlando Springs, and hydrogen sulfide was detected in Salt and Silver Glen Springs. Local non-atmospheric sources of CFCs likely are the cause of elevated CFC-12 concentrations in six springs and CFC-113 concentrations in two springs. Concentrations of these two compounds are termed "contaminated" when they are higher than those possible for equilibrium with modern air (Table 3 ). The $\mathrm{SF}_{6}$ concentrations are higher than those expected from equilibration with modern atmospheric concentrations in 2 of 11 spring waters (Palm and Sanlando), and contamination from non-atmospheric sources cannot be excluded at other sites where $\mathrm{SF}_{6}$ apparent ages are much younger (lower) than those estimated from CFCs and ${ }^{3} \mathrm{H} /{ }^{3} \mathrm{He}_{\text {trit }}$. This is especially true for Blue Spring, but also for Ponce de Leon, Starbuck, and Wekiwa Springs (Table 4).

Apparent PFM ages for ${ }^{3} \mathrm{H} /{ }^{\beta} \mathrm{He}_{\text {trit }}$ data ranged from 14 to 32 years, and generally are consistent with apparent CFC113 ages (Tables 3 and 4). Median apparent ${ }^{3} \mathrm{H} /{ }^{3} \mathrm{He}_{\text {trit }}$ ages are older for the four $\mathrm{Na}-\mathrm{Cl}$ type spring waters (25 years) than for the six $\mathrm{Ca}-\mathrm{HCO}_{3}$ type spring waters (20 years) or for the mixed water type (Ponce de Leon Spring, 22 years) (Table 4). Terrigenic ${ }^{4} \mathrm{He}$ concentrations (expressed as a percentage of total ${ }^{4} \mathrm{He}$ ) generally were less than $6 \%$, with the exception of two Na-Cl type springs, Silver Glen (7\%) and Salt (24\%). Non-tritiogenic ${ }^{3} \mathrm{H}$ resulting from terrigenic sources are adjusted using an $\mathrm{R}_{\mathrm{terr}}\left({ }^{3} \mathrm{He} /{ }^{4} \mathrm{He}\right.$ ratio) of $2 \times 10^{-8}$ (Schlosser et al. 1988). ${ }^{3} \mathrm{H} /{ }^{\beta} \mathrm{He}_{\text {trit }}$ apparentage calculations have been shown to be highly sensitive to the amount of terrigenic ${ }^{4} \mathrm{He}$ (from decay of Uraniumseries radionuclides and excess air) (e.g., Plummer et al. 2000; Katz et al. 2004). If the fraction of terrigenic $\mathrm{He}$ is large, the ${ }^{3} \mathrm{He} /{ }^{4} \mathrm{He}$ ratio of the terrigenic $\mathrm{He}, \mathrm{R}_{\text {terr }}$, needs to be known accurately. If this ratio is allowed to vary over 2 orders of magnitude (somewhat unlikely, but useful for illustrating estimates of age uncertainty), for an $\mathrm{R}_{\text {terr }}$ of $2 \times 10^{-7}$, apparent ages would be younger by only 0.8 years for Silver Glen, and 1.7 years for Salt Springs, which nearly fall within the analytical uncertainty (Table 4). An $R_{\text {terr }}$ of $2 \times 10^{-9}$ yielded similar ages for these two springs compared to those calculated using an $\mathrm{R}_{\text {terr }}$ of $2 \times 10^{-8}$.

Diffusive losses of ${ }^{3} \mathrm{He}_{\text {trit }}$ also can affect ${ }^{3} \mathrm{H} /{ }^{3} \mathrm{He}_{\text {trit }}$ apparent ages. To account for possible loss of ${ }^{3} \mathrm{He}_{\text {trit }}$ and its effect on ${ }^{3} \mathrm{H} /{ }^{3} \mathrm{He}_{\text {trit }}$ apparent ages, it is assumed that 


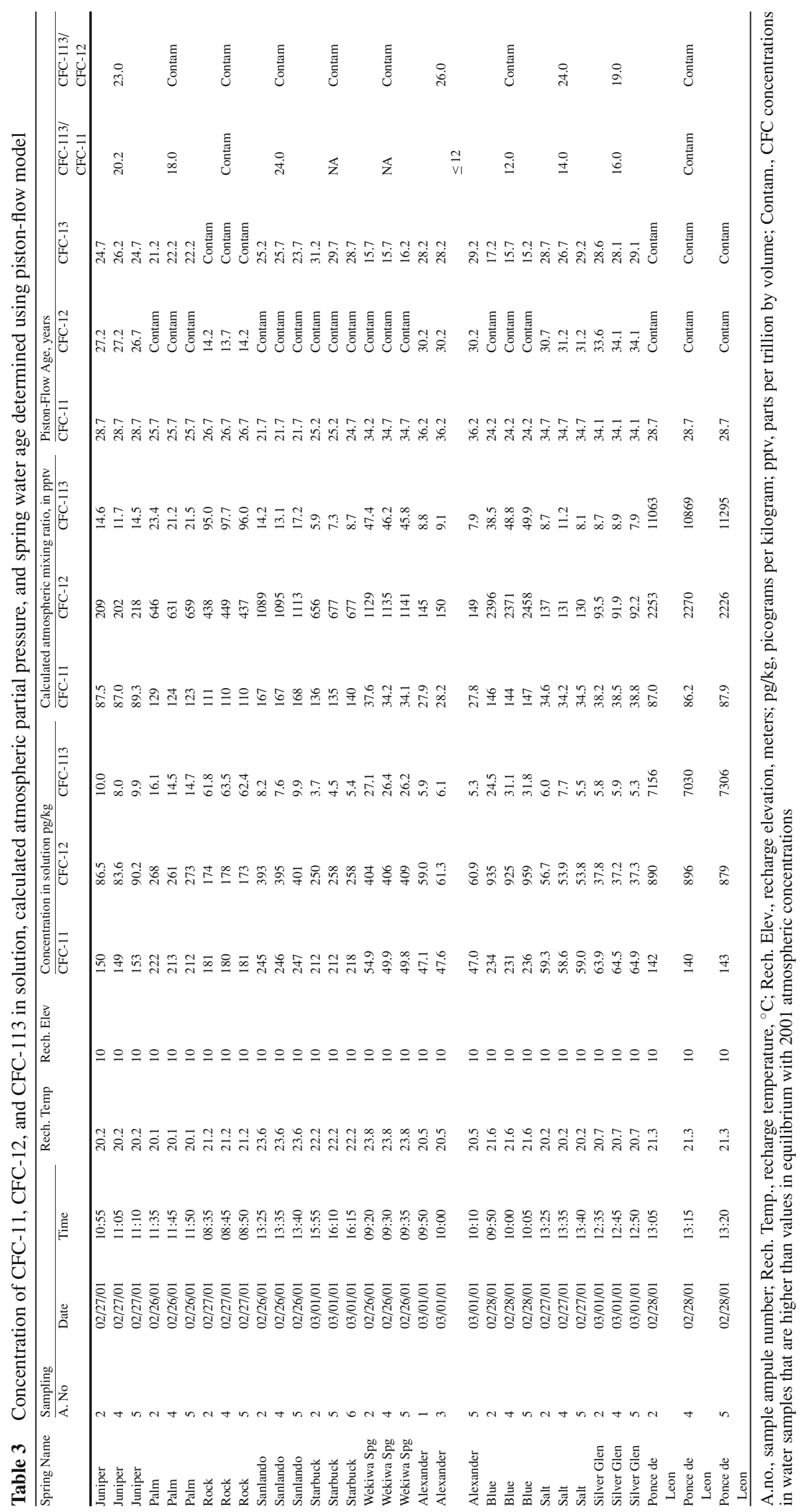




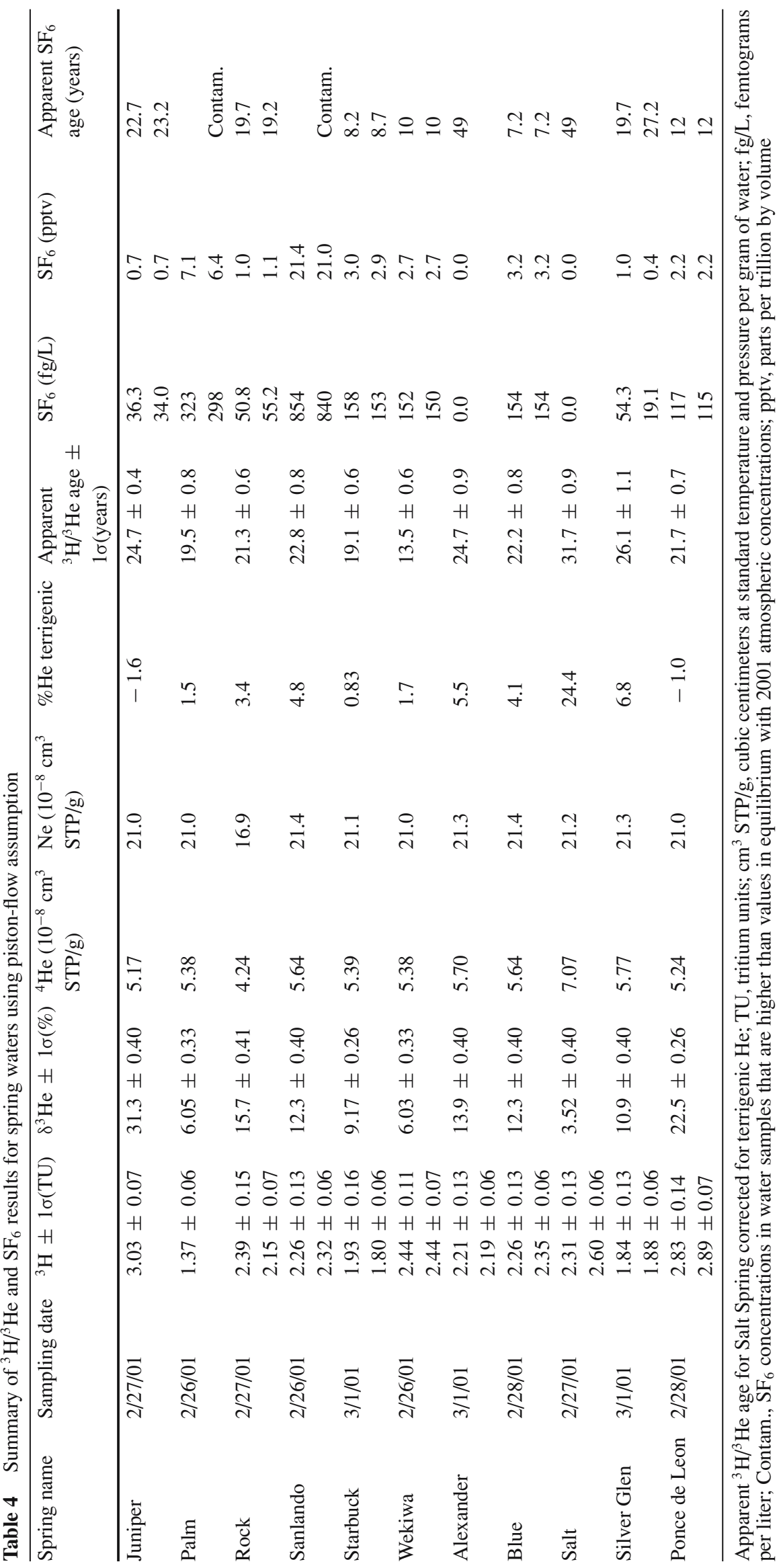


${ }^{3} \mathrm{H}$ concentrations were $2 \mathrm{TU}$ in pre-bomb $(\sim 1955)$ rainfall (Thatcher 1962). Based on this assumption, 2 TU in ${ }^{3} \mathrm{He}_{\text {trit }}$ was added to the calculated ${ }^{3} \mathrm{He}_{\text {trit }}$ concentration, the resulting apparent ages increased by only about 4-6 years.

With the exception of Alexander and Salt Springs, $\mathrm{SF}_{6}$ apparent ages generally were lower than those estimated from concentrations of CFCs and ${ }^{3} \mathrm{H} /{ }^{3} \mathrm{He}_{\text {trit }}$. The lack of concordancy of tracer ages and generally younger ${ }^{3} \mathrm{H} /{ }^{3} \mathrm{He}_{\text {trit }}$ apparent ages compared to those from CFCs indicate the likelihood of mixtures of waters from different parts of the aquifer.

One way to assess the extent of mixing is to compare the reconstructed original ${ }^{3} \mathrm{H}$ content (initial ${ }^{3} \mathrm{H}$ at the time of recharge) of the spring water samples $\left({ }^{3} \mathrm{H}+{ }^{3} \mathrm{He}_{\text {trit }}\right)$ with the historical record of ${ }^{3} \mathrm{H}$ in rainfall (Aeschbach-Hertig et al. 1998). The record of ${ }^{3} \mathrm{H}$ in rainfall from the IAEA network station in Ocala, Florida, was used for this comparison and presented in Fig. 6. It was assumed that the local ${ }^{3} \mathrm{H}$ input history for each spring basin is closely approximated by this record. The ${ }^{3} \mathrm{H}+{ }^{3} \mathrm{He}_{\text {trit }}$ concentrations in water from each spring are plotted relative to the input history by assuming that the time of infiltration for each spring is obtained by subtracting the ${ }^{3} \mathrm{H} /{ }^{3} \mathrm{He}_{\text {trit }}$ apparent age from the sampling date. Corresponding to these points on the time $x$-axis, the "initial tritium" represents the sum of the measured ${ }^{3} \mathrm{H}$ and ${ }^{3} \mathrm{He}_{\text {trit }}$ concentrations ( $y$-axis). If water recharging the UFA contains the initial ${ }^{3} \mathrm{H}$ content as indicated by the input curve for Ocala rainfall, and subsequently was not affected by mixing or diffusive losses of ${ }^{3} \mathrm{He}_{\text {trit }}$, then all initial ${ }^{3} \mathrm{H}$ data for springs should fall on this ${ }^{3} \mathrm{H}$ input curve. It is evident that for most springs, concentrations of ${ }^{3} \mathrm{H}+{ }^{3} \mathrm{He}_{\text {trit }}$ plot below the ${ }^{3} \mathrm{H}$ input curve (Salt Springs plots well below this curve; Fig. 6) and are affected by the mixing of waters from different parts of the aquifer system. Concentrations of ${ }^{3} \mathrm{H}+{ }^{3} \mathrm{He}_{\text {trit }}$ usually plot below the IAEA curve around bomb-peak years (Ekwurzel et al. 1994). Large gradients of tritium around the bomb peak could create mixtures that would lower the ${ }^{3} \mathrm{H}+{ }^{3} \mathrm{He}_{\text {trit }}$ concentrations in this region of the plot. Mixing around the bomb peak tends to pull ages toward this peak from either side, resulting in some apparent ages becoming younger while other apparent ages are becoming older.

\section{Evaluation of mixing scenarios using lumped parameter models}

For spring waters where $\mathrm{CFCs}$ and $\mathrm{SF}_{6}$ contamination are unlikely, lack of agreement between tracer apparent ages may result from complex mixtures of groundwater from different parts of the UFA. In an attempt to assess and quantify various groundwater mixing scenarios from the simultaneous evaluation of multiple tracer data, CFC and $\mathrm{SF}_{6}$ data were included where contamination from nonatmospheric sources was presumed unlikely. Concentration data for CFC-12, CFC-113, $\mathrm{SF}_{6}$, and ${ }^{3} \mathrm{H} /{ }^{\beta} \mathrm{He}_{\text {trit }}$ were plotted relative to theoretical output curves (from FLOWPC;

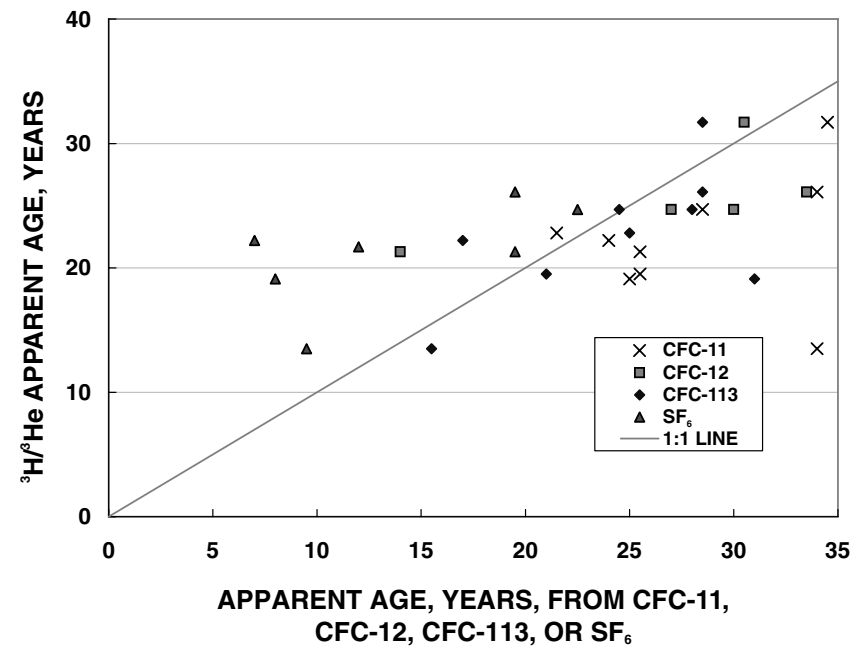

Fig. 5 Comparison of apparent ages (piston-flow model) estimated from ${ }^{3} \mathrm{H} /{ }^{3} \mathrm{He}_{\text {trit }}$ and those from halogenated tracer compounds

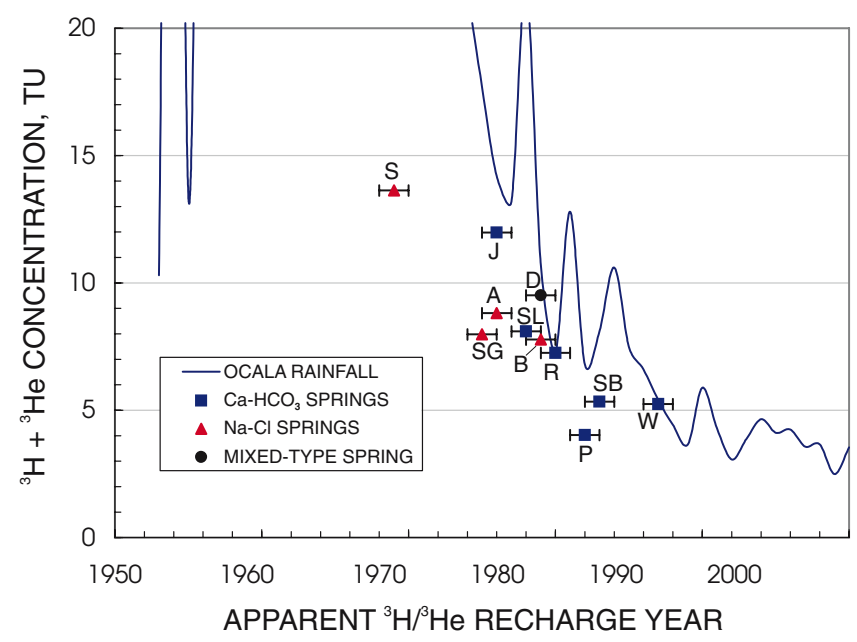

Fig. 6 Comparison of measured ${ }^{3} \mathrm{H}+{ }^{3} \mathrm{He}_{\text {trit }}$ concentrations with the ${ }^{3} \mathrm{H}$ input curve for rainfall, Ocala, Florida. See Table 1 for abbreviations of spring names

Maloszewski and Zuber 1996) for various lumped parameter models representing different groundwater flow scenarios: dispersion (DM, using $P_{\mathrm{D}}$ values of 0.05 and 0.5 ); exponential mixing (EM, with and without a tracer-free old-water component); combined exponential-piston flow (EPM); and simple binary mixing of shallow and deep waters (BM). Concentration data for CFC-12, CFC-113, and $\mathrm{SF}_{6}$ are each plotted in Figs. 7, 8 and 9 (respectively) as a function of ${ }^{3} \mathrm{H} /\left({ }^{3} \mathrm{H}+{ }^{3} \mathrm{He}_{\text {trit }}\right)$, which represents a surrogate for water age. Values of ${ }^{3} \mathrm{H} /\left({ }^{3} \mathrm{H}+{ }^{3} \mathrm{He}_{\text {trit }}\right)$ near zero correspond to old waters, whereas values approaching 1.0 correspond to young (recently recharged) waters (Böhlke 2002).

Most tracer concentrations in springs tend to cluster along curves that represent binary mixtures of waters of varying age. For instance, CFC-12 and ${ }^{3} \mathrm{H} /\left({ }^{3} \mathrm{H}+{ }^{3} \mathrm{He}_{\text {trit }}\right)$ data (Fig. 7) are bounded by curves representing binary mixtures of recent water (recharged $\geq 1995$ ) with water recharged dur- 


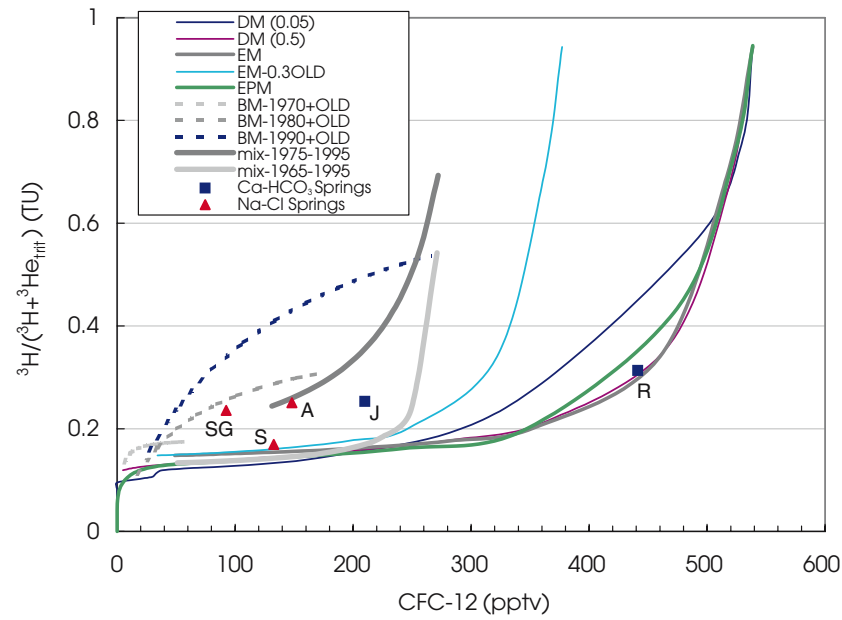

Fig. 7 Plot of theoretical curves from various lumped parameter models and measured concentration data for $\mathrm{CFC}-12$ and ${ }^{3} \mathrm{H} /\left({ }^{3} \mathrm{H}+{ }^{3} \mathrm{He}_{\text {trit }}\right)$. Dispersion model $(D M)$ curves are shown for dispersion parameter values of 0.05 and 0.5 . Exponential model $(E M)$ curves are shown for old-water mixing fractions of zero and 0.3 . Endmember years are shown for various binary mixing models $(B M M)$. See Table 1 for abbreviations of spring names

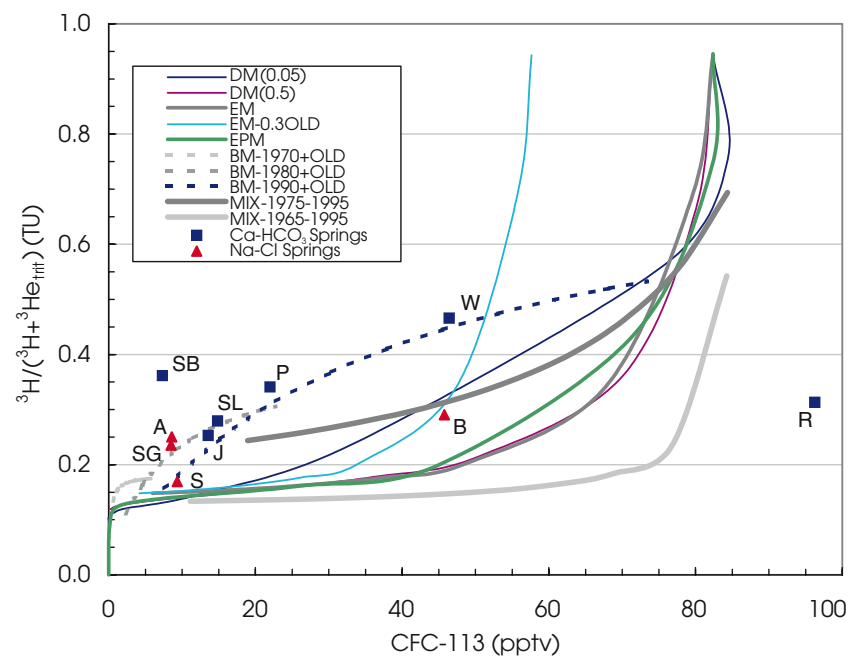

Fig. 8 Plot of theoretical curves from various lumped parameter models and measured concentration data for CFC-113 and ${ }^{3} \mathrm{H} /\left({ }^{3} \mathrm{H}+{ }^{3} \mathrm{He}_{\text {trit }}\right)$. Dispersion model $(D M)$ curves are shown for dispersion parameter values of 0.05 and 0.5 . Exponential model $(E M)$ curves are shown for old-water mixing fractions of zero and 0.3 . Endmember years are shown for various binary mixing models $(B M M)$. See Table 1 for abbreviations of spring names

ing 1965 or 1975 for four springs (three $\mathrm{Na}-\mathrm{Cl}$ and one $\mathrm{Ca}-\mathrm{HCO}_{3}$ spring waters), assuming no non-atmospheric $\mathrm{CFC}-12$ contamination sources. Four $\mathrm{Ca}-\mathrm{HCO}_{3}$ springs with presumably non-contaminated CFC-113 data cluster along binary mixing curves that represent recharge during 1980 or 1990 with an old tracer-free component (Fig. 8). Young-water mixing fractions are 0.6 and 0.3 for Wekiwa and Palm Springs (1990), and 0.6 and 0.7 for Juniper and Sanlando Springs (1980). CFC-113 and ${ }^{3} \mathrm{H} /\left({ }^{3} \mathrm{H}+{ }^{3} \mathrm{He}\right.$ trit $)$ concentration data for Silver Glen and Alexander Springs $(\mathrm{Na}-\mathrm{Cl}$ type waters) indicate mixing fractions of 0.4 for

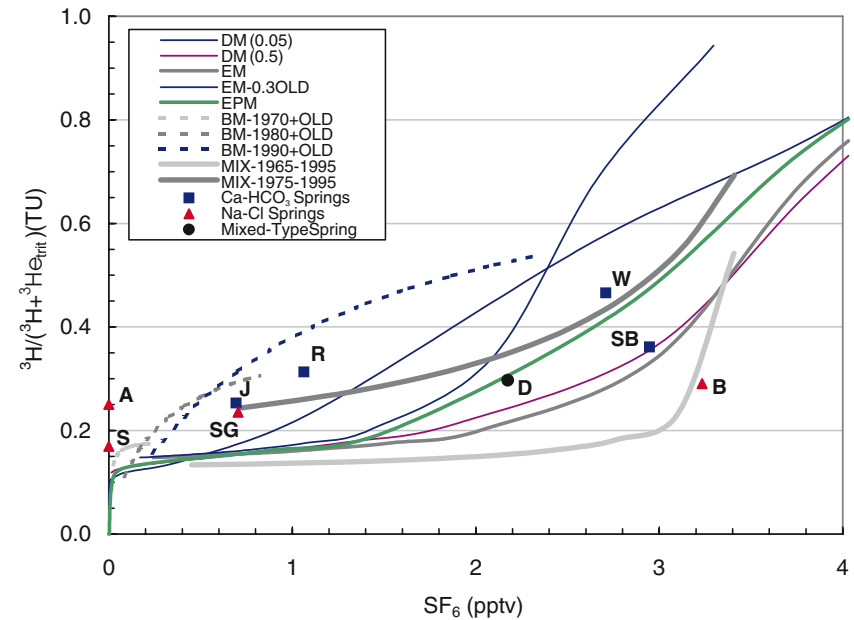

Fig. 9 Plot of theoretical curves from various lumped parameter models and measured concentration data for $\mathrm{SF}_{6}$ and ${ }^{3} \mathrm{H} /\left({ }^{3} \mathrm{H}+{ }^{3} \mathrm{He}_{\text {trit }}\right)$. Dispersion model $(D M)$ curves are shown for dispersion parameter values of 0.05 and 0.5 . Exponential model $(E M)$ curves are shown for old-water mixing fractions of zero and 0.3. Endmember years are shown for various binary mixing models $(B M M)$. See Table 1 for abbreviations of spring names

1980s water. Tracer data for Salt Springs plot near a binary mixing curve of 1990 recharge $(10 \%)$ with old tracer-free water, but also near curves for the dispersion model, and exponential mixing with a tracer-free old-water component (mixing fraction of 0.3). Estimated mean transit times for Salt Springs are 50, 80, and 120 years, based on theoretical output curves for dispersion $\left(P_{\mathrm{D}}=0.05\right.$ and 0.5$)$ and exponential models, respectively. $\mathrm{SF}_{6}$ and ${ }^{3} \mathrm{H} /\left({ }^{3} \mathrm{H}+{ }^{3} \mathrm{He}_{\text {trit }}\right)$ concentration data for four $\mathrm{Ca}-\mathrm{HCO}_{3}$ spring waters appear to be bounded by binary mixing curves representing several possible mixtures of post-bomb (>1965) waters. Salt and Alexander Springs contain essentially no $\mathrm{SF}_{6}$, thus do not fall near any mixing model curves. However, two other $\mathrm{Na}-\mathrm{Cl}$ type spring waters, Silver Glen and Blue, appear to be mixtures of recent water (1990) with water recharged during 1965 or 1975 (Fig. 9).

Tritium $\left({ }^{3} \mathrm{H}\right)$ and ${ }^{3} \mathrm{H} /\left({ }^{3} \mathrm{H}+{ }^{3} \mathrm{He}_{\text {trit }}\right)$ concentration data also tend to cluster along binary mixing curves that represent mixtures of relatively recent recharge (1980 or 1990) with old pre-bomb (tracer-free) waters; this is shown in Fig. 10. Lower ${ }^{3} \mathrm{H}$ concentrations in spring waters than those measured in rainfall during the past 2-3 decades (and accounting for radioactive decay) are consistent with mixtures of tracer-free old waters. Mixing fractions for $\mathrm{Ca}-\mathrm{HCO}_{3}$ spring waters range from 0.4 (Palm) to 0.7 (Wekiwa) for 1990 water; and 0.8 (Sanlando) and 0.99 (Rock) for 1980 water. The ${ }^{3} \mathrm{H}$ and ${ }^{3} \mathrm{He}_{\text {trit }}$ data for Salt Springs plot near a binary mixing curve that represents a mixture of 30\% 1970 water with an old tracer-free water. The ${ }^{3} \mathrm{H}$ and ${ }^{3} \mathrm{He}_{\text {trit }}$ data also cluster along a theoretical output curve for an exponential model that contains $30 \%$ old water (Fig. 10). Mean transit times, estimated based on their location on modeled curves, range from 8 (Wekiwa Spring) to 75 years for Salt Springs. 


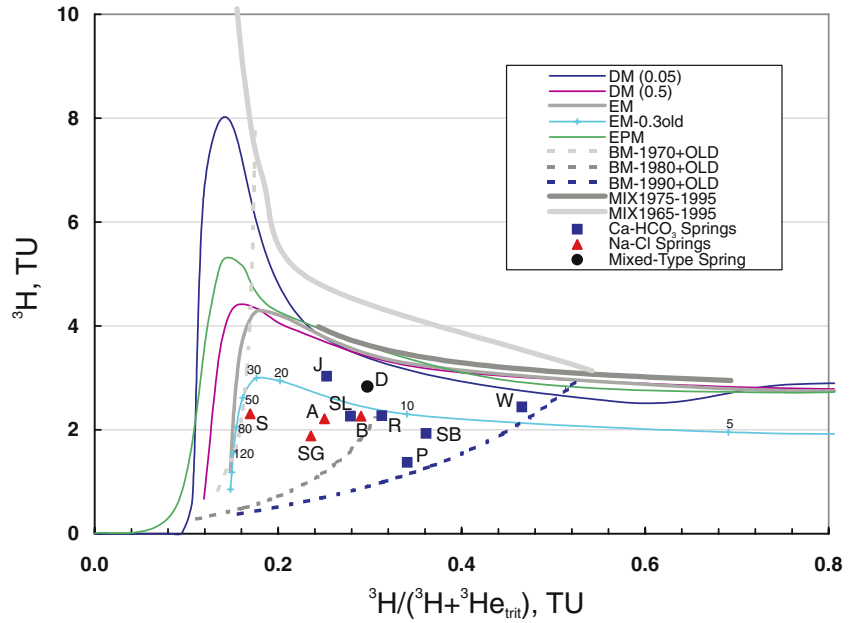

Fig. 10 Plot of theoretical curves from various lumped parameter models and measured concentration data for ${ }^{3} \mathrm{H}$ and ${ }^{3} \mathrm{H} /\left({ }^{3} \mathrm{H}+{ }^{3} \mathrm{He}\right.$ trit $)$. Numbers shown on exponential mixing $(E M)$ curve denote mean transit times from model. Dispersion model $(D M)$ curves are shown for dispersion parameter values of 0.05 and 0.5 . Exponential model $(E M)$ curves are shown for old-water mixing fractions of zero and 0.3 . End-member years are shown for various binary mixing models $(B M M)$. See Table 1 for abbreviations of spring names

CFC ratios generally had somewhat limited use in providing spring-water ages given the relatively high incidence of CFC-12 contamination (Table 3), but provided important information about mixing scenarios. Ratios of CFC113/CFC-11 and CFC-113/CFC-12 were used to estimate ages for spring waters where contamination was not suspected. CFC-ratio ages for these spring waters were consistently younger than ages obtained from individual CFC compounds (Table 3). Older ages for individual CFC compound most likely result from a mixture of young water with an old (tracer-free) component, which lowers the concentration of that compound and gives an older age. Since the CFC ratio is unaffected by dilution with an old water, the ratio age represents that of the young fraction and allows the calculation of the young water fraction. Assuming a binary mixture, the young water fraction ranges from $10 \%$ for Salt, Starbuck, and Alexander Springs to 50\% for Blue and Wekiwa Springs.

\section{Spring water ages and mixing}

Although no single model consistently fits the combined tracer data (given in Table 5), several trends emerge from the simultaneous evaluation of $\mathrm{CFCs}, \mathrm{SF}_{6},{ }^{3} \mathrm{H}$, and ${ }^{3} \mathrm{He}_{\text {trit }}$ concentration data. The combined tracer data are consistent with several possible mixing scenarios, most of which include a tracer-free old-water component. Estimating the age range of the old-water component would provide additional useful information about the hydrologic characteristics of the aquifer system. As the young-fraction percentage increases in a binary mixture, the age of the old-water fraction increases exponentially. Given mean groundwater transit times of 20-80 years and fractions of old water of about $20-30 \%$, the maximum age of the old-water com- ponent would range from 40 to about 240 years. Unfortunately, this range of ages represents the low end of the ${ }^{14} \mathrm{C}$ age dating range, where ${ }^{14} \mathrm{C}$ ages have a high degree of uncertainty. As the age of the old fraction increases with decreasing old-water fraction, dilution with young water would preclude dating of a possibly very old-water component. All adjusted ${ }^{14} \mathrm{C}$ ages for the $\mathrm{Ca}-\mathrm{HCO}_{3}$ spring waters (Fontes-Garnier model in NETPATH) are modern, as shown in Table 6.

Salt Springs, which contains one of the largest fractions of old water, has a ${ }^{14} \mathrm{C}$ concentration of $21.5 \mathrm{pmc}$. Wekiwa Springs, in contrast, containing one of the largest fractions of young water, has a ${ }^{14} \mathrm{C}$ concentration of approximately 50.0 pmc. The ${ }^{14} \mathrm{C}$ concentration in Salt Springs can be explained by mixing of about equal proportions of UFA water having a ${ }^{14} \mathrm{C}$ concentration of $50.4 \mathrm{pmc}$ and LFA water having a ${ }^{14} \mathrm{C}$ concentration of $6.7 \mathrm{pmc}$. The ${ }^{14} \mathrm{C}$ age for UFA water is modern. An exact age for LFA water cannot be determined, but depends on the model used to interpret the measured ${ }^{14} \mathrm{C}$. The ${ }^{14} \mathrm{C}$ age for LFA water ranges from 12,800 years (Fontes and Garnier (1979) model) to 17,900 years (Tamers (1975) model, in NETPATH). The above ages for LFA water are supported by its delta oxygen-18 content $(-1.94 \%$ ), which is slightly higher (enriched) than modern rainfall, and is consistent with stable isotope enrichment during the last glacial maximum (Plummer 1993).

Similarly, ${ }^{14} \mathrm{C}$ ages for other $\mathrm{Na}-\mathrm{Cl}$ type springs and the mixed-type spring (Ponce de Leon) can be explained by the mixing of various fractions of rainwater or UFA water with older LFA water (Table 2). The ${ }^{14} \mathrm{C}$ ages for both UFA and LFA waters depend on the models used to interpret their measured ${ }^{14} \mathrm{C}$ concentrations (Table 6). If it is assumed that the apparent $\left({ }^{3} \mathrm{H} /{ }^{3} \mathrm{He}_{\text {trit }}\right)$ age represents the age of the young fraction of water in spring water mixtures, then for relatively young waters (mean transit times $<20$ yrs), apparent ages and mean transit times are similar (within \pm 4 years), which indicates that $\mathrm{Ca}-\mathrm{HCO}_{3}$ type spring waters contain predominantly post-bomb ${ }^{3} \mathrm{H}$. $\mathrm{Na}-\mathrm{Cl}$ type spring waters with mean transit times $\geq 50$ years, have apparent ages that are much younger than the estimated mean transit times. This discrepancy may reflect the apparent age of the young-water fraction (Plummer et al. 1998) in mixtures of young (post-bomb ${ }^{3} \mathrm{H}$ ) and old (pre-bomb ${ }^{3} \mathrm{H}$ ) waters. Apparent ages derived from ${ }^{3} \mathrm{H}$ and ${ }^{3} \mathrm{He}_{\text {trit }}$ data generally will not be equal to the mean age of all flow lines contributing to the spring, because ${ }^{3} \mathrm{H}$ concentrations are not linear functions of age (Cook and Böhlke 1999). Differences in apparent ages $\left({ }^{3} \mathrm{H} /{ }^{3} \mathrm{He}_{\text {trit }}\right)$ and estimated mean transit times also may result from processes that alter concentrations of ${ }^{3} \mathrm{H}$ and ${ }^{3} \mathrm{He}_{\text {trit }}$ in the subsurface. For example, ${ }^{3} \mathrm{H}$ and ${ }^{3} \mathrm{He}_{\text {trit }}$ concentration gradients can differ because their aqueous diffusion coefficients differ by about a factor of 4 (Solomon and Cook 1999). Other studies have shown that the ${ }^{3} \mathrm{H}$ input was affected by hydrodynamic dispersion (Solomon and Sudicky 1991; Reilly et al. 1994). Diffusive loss of ${ }^{3} \mathrm{He}_{\text {trit }}$ in the unsaturated zone has been documented, and resulted in calculated ${ }^{3} \mathrm{H} /{ }^{3} \mathrm{He}_{\text {trit }}$ ages that were lower than those for ${ }^{85} \mathrm{Kr}$ (krypton), which had minor diffusive losses (Weise et al. 1992). 
Table 5 Summary of results for lumped parameter models for various combinations of tracers using exponential mixing (EM), binary mixing (BMM)

\begin{tabular}{|c|c|c|c|}
\hline Spring name & ${ }^{3} \mathrm{H}$ vs. ${ }^{3} \mathrm{H} /\left({ }^{3} \mathrm{H}+{ }^{3} \mathrm{He}\right)$ & CFC-12 vs. ${ }^{3} \mathrm{H} /\left({ }^{3} \mathrm{H}+{ }^{3} \mathrm{He}\right)$ & CFC-113 vs. ${ }^{3} \mathrm{H} /\left({ }^{3} \mathrm{H}+{ }^{3} \mathrm{He}\right)$ \\
\hline Juniper & EM; 18 yr; 0.3 old & BMM: 0.4 (1980); 0.6 (old) & BMM: 0.2 (1990), 0.8 (old) \\
\hline Palm & BMM 0.4 (1990), 0.6 (old) & - & BMM: 0.3 (1990), 0.7 (old) \\
\hline Sanlando & EM: 12 yr; 0.3 (old) & - & BMM 0.20 (1990), 0.80 (old) \\
\hline Starbuck & $\begin{array}{l}\text { EM: } 12 \text { yr; } 0.3 \text { (old) BMM: } 0.40 \\
\text { (1990), } 0.6 \text { (old) }\end{array}$ & - & - \\
\hline Alexander & EM: 15 yr; 0.3 (old) & BMM: 0.25 (1990); 0.75 (old) & BMM: 0.15 (1990), 0.85 (old) \\
\hline Blue & EM: 12 yr; 0.3 (old) & - & EM: 12 yr; 0.3 (old) \\
\hline Salt & $\begin{array}{l}\text { EM: } 70 \text { yr, } 0.3 \text { (old) BMM: } 0.3 \\
\text { (1970), } 0.7 \text { (old) }\end{array}$ & BMM 0.25 (1970) & BMM 0.10 (1990) \\
\hline Silver Glen & - & BMM 0.2 (1990), 0.8 (old) & BMM 0.15 (1990), 0.85 (old) \\
\hline
\end{tabular}

old, denotes waters recharged prior to 1940 that contain near zero concentrations of tritium and CFCs; -, no plausible models found for mean transit time; yr, mean transit time of groundwater discharging from spring from EM, in years; end-member mixing fractions are given for BMM

Other factors, such as rainfall source, timing of recharge, and seasonal variability of ${ }^{3} \mathrm{H}$ in rainfall can affect ${ }^{3} \mathrm{H}$ concentrations in recharge water (Ekwurzel et al. 1994) and may contribute to the low $\left({ }^{3} \mathrm{H}+{ }^{3} \mathrm{He}_{\text {trit }}\right)$ concentrations in Salt Springs relative to ${ }^{3} \mathrm{H}$ input in rainfall. During years of low recharge to the UFA (mid-1950s, early 1960s, and 1967-1968), more closely spaced isochrons could result in a greater potential for mixing and a correspondingly lower resolution in delineating the ${ }^{3} \mathrm{H}$ signal from atmospheric nuclear testing (Dunkle et al. 1993).

Estimated apparent ages, mean transit times, and mixing fractions for these spring waters are applicable for hydrologic conditions at the time of sampling. Spring water samples generally were collected after a low-rainfall period and may not contain components of very recent recharge that likely would be more abundant during high-flow conditions. Consequently, it is possible that recharge of recent origin from shorter groundwater flow paths and/or from sinkholes that are hydraulically connected to the UFA could contribute a larger fraction of the total spring discharge at high flow. Relative ages of representative spring waters in the Chesapeake Bay region appeared to be slightly younger, on average, during high-flow conditions than during low-flow conditions (Focazio et al. 1998). Also, springs in the Woodville Karst Plain south of Tallahassee, Florida, showed substantial increases in dissolved organic carbon and tannic acid concentrations following a high-rainfall period, indicating the contribution of recent (days) surface-water inflow (Katz et al. 2004).

\section{Spring-water age and water chemistry}

Spring water ages from a single "snapshot" in time may provide an opportunity to identify trends in groundwater chemistry over larger timescales (Aeschbach-Hertig et al. 1998). Consistent trends have been found between spring water ages and various chemical indicators, such as dissolved oxygen and nitrate- $\mathrm{N}$ concentrations for other springs systems (Katz et al. 1999; Katz 2004). Mean transit times and apparent ages $\left({ }^{3} \mathrm{H} /{ }^{3} \mathrm{He}_{\text {trit }}\right)$ of the 11 spring waters were tested for their degree of correlation (Spearman's rho non-parametric statistic) with the concentrations of several chemical and physical variables (dissolved oxygen, $\mathrm{pH}$, nitrate- $\mathrm{N}$, phosphate, major ions, silica, and saturation indices with respect to calcite and dolomite). Statistically significant $(p<0.02)$ inverse correlations were noted between nitrate- $\mathrm{N}$ and phosphate-P concentrations, and spring water apparent ages. A similar trend was observed between nitrate-N and the age for 24 springs with varying flows in the Suwannee River basin of northern Florida (Katz et al. 1999). Although the apparent age or transit time of groundwater discharging from springs does not necessarily represent the age of the nitrate- $\mathrm{N}$ constituent that the water carries, it is of interest that the springs discharging younger waters tend to have higher nitrate-N concentrations, indicating that elevated nitrate- $\mathrm{N}$ concentrations are contributed from more recent recharge. It is important to note, however, that there are many other factors affecting nitrate- $\mathrm{N}$ concentrations in groundwater discharging from springs such as the time distribution of nitrogen loading to the land surface, the proximity of nitrogen sources to a spring, and local climatic variations. Although not statistically significant, there was a slight trend between age and saturation indices (SI) with respect to calcite and dolomite. This is consistent with chemical characteristics of older waters, in which dissolution of calcite in limestone increases and approaches equilibrium SI values of zero or slightly above zero. The $\mathrm{Ca}-\mathrm{HCO}_{3}$ type spring waters tended to have SI values less than zero with respect to calcite and dolomite, whereas $\mathrm{Na}-\mathrm{Cl}$ type spring waters have SI values close to or slightly above zero. 


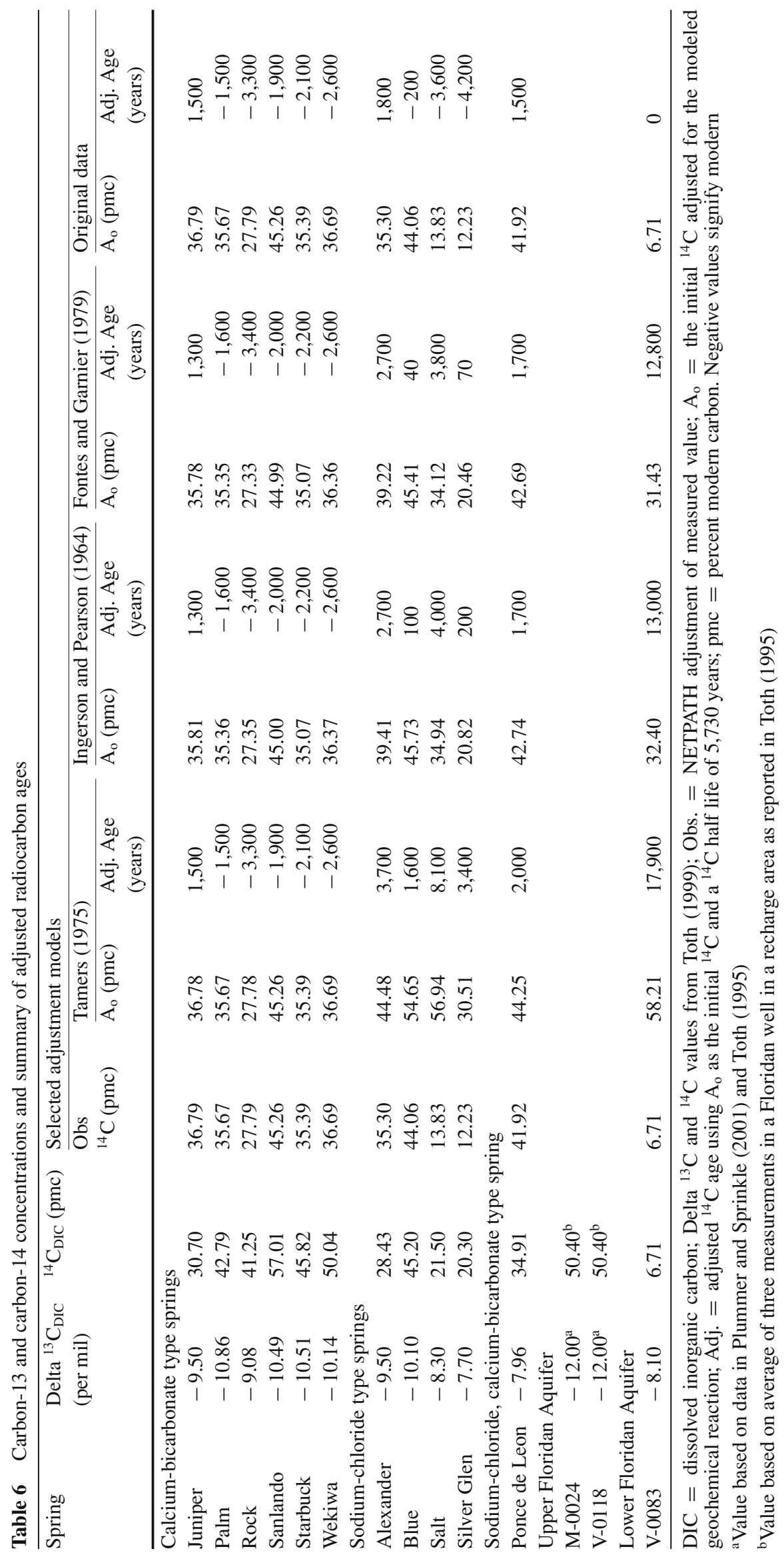




\section{Conclusions}

Concentrations of major ions, nutrients, chlorofluorocarbons (CFCs; $\mathrm{CCl}_{3} \mathrm{~F}, \mathrm{CCl}_{2} \mathrm{~F}_{2}$, and $\left.\mathrm{C}_{2} \mathrm{Cl}_{3} \mathrm{~F}_{3}\right)$, tritium $\left({ }^{3} \mathrm{H}\right)$, helium-3 $\left({ }^{3} \mathrm{He}_{\text {trit }}\right)$, sulfur hexafluoride $\left(\mathrm{SF}_{6}\right)$, and noble gases were used to better understand groundwater flow patterns, groundwater age, and the evolution of spring water chemistry within the Floridan aquifer system of northeast Florida. Geochemical models were developed for dominant reactions that occur within the spring basins, including the mixing of waters from the Upper and Lower Floridan aquifers. Some of the conclusions are as follows:

1. The lack of agreement between tracer apparent ages for spring waters results from complex mixtures of groundwater from different parts of the Floridan aquifer system. $\mathrm{Ca}-\mathrm{HCO}_{3}$ springs (Juniper, Palm, Rock, Sanlando, Starbuck, and Wekiwa) contain mixtures of young waters, whereas, $\mathrm{Na}-\mathrm{Cl}$ (Alexander, Blue, Salt, and Silver Glen) and the mixed-type (Ponce de Leon) springs contain mixtures with varying proportions of Lower Floridan aquifer water. Median apparent ${ }^{3} \mathrm{H} /{ }^{3} \mathrm{He}_{\text {trit }}$ ages are older for the four $\mathrm{Na}-\mathrm{Cl}$ springs (25 years) than for the six $\mathrm{Ca}-\mathrm{HCO}_{3}$ springs (20 years) or for the mixed-type spring (22 years).

2. Even though no single lumped parameter model fit all environmental tracer data for all springs, most tracer concentrations tend to cluster along curves that represent binary mixtures of waters. Tracer data for four $\mathrm{Ca}-\mathrm{HCO}_{3}$ springs cluster along binary mixing curves that represent recharge during 1980 or 1990 with an old, tracer-free (pre-bomb) component. Young-water (1990) mixing fractions are 0.6 and 0.3 for Wekiwa and Palm Springs, respectively, and 0.6 and 0.7 for Juniper and Sanlando Springs (1980), respectively. Two Na-Cl springs (Silver Glen and Blue) appear to be consistent with binary mixtures of 1990 water with water recharged during 1965 or 1975.

3. Quantification of the young fraction in binary mixtures is complicated by the slowing and turnover of CFC atmospheric concentrations after 1993, possible introduction of non-atmospheric sources of CFCs, non-linearity of mixing tracer concentrations from different age waters, and possible microbial degradation of CFC-11 and CFC113 in spring systems where slight reducing conditions are present.

4. The chemical composition of spring waters can be used as a qualitative indicator of age and groundwater residence time. Nitrate- $\mathrm{N}$ concentrations are inversely related to apparent ages of spring waters. Although the apparent age or transit time of groundwater discharging from springs does not necessarily represent the age of the nitrate- $\mathrm{N}$ constituent that the water carries, springs discharging younger waters (1990) tend to have higher nitrate- $\mathrm{N}$ concentrations, indicating that elevated nitrate- $\mathrm{N}$ concentrations are contributed from more recent recharge. This suggests that nitrate- $\mathrm{N}$ concentrations observed in springs is related to current land use practices as opposed to those that occurred 25 or more years ago.

5. For future work, tracer analyses should be tailored to spring water type. For example, carbon-14 should be sampled in $\mathrm{Na}-\mathrm{Cl}$ and mixed spring waters, but not in $\mathrm{Ca}-\mathrm{HCO}_{3}$ spring waters. $\mathrm{Na}-\mathrm{Cl}$ and mixed spring water types arise from mixtures of Lower Floridan aquifer water; whereas $\mathrm{Ca}-\mathrm{HCO}_{3}$ spring waters contain mixtures dominated by young waters. Samples of spring waters should be analyzed for carbon-13 to determine dominant geochemical reactions that have occurred along flowpaths to springs.

Acknowledgements This study was funded jointly by the St. Johns River Water Management District and the US Geological Survey. The authors thank J. Wayland for water sampling assistance; E. Busenberg, L.N. Plummer, J. Wayland, and G. Casile for CFCs and $\mathrm{SF}_{6}$ analyses; $\mathrm{P}$. Schlosser for $\mathrm{H}, \mathrm{Ne}$, and $\mathrm{He}$ isotope analyses; and G.G. Phelps, A.J. Long, P. Olcott, and two anonymous reviewers for their comments that were helpful in revising this manuscript.

\section{References}

Aeschbach-Hertig W, Schlosser P, Stute M, Simpson HJ, Ludin A, Clark JF (1998) A ${ }^{3} \mathrm{H} /{ }^{3} \mathrm{He}$ study of ground water flow in a fractured bedrock aquifer. Ground Water 36:661-670

Böhlke JK (2002) Groundwater recharge and agricultural contamination. Hydrogeol J 10:153-179

Boniol D, Williams M, and Munch D (1993) Mapping recharge to the Floridan aquifer using a geographic information system, Technical Publication SJ93-5, St. Johns River Water Management District Palatka, FL, $41 \mathrm{p}$

Busenberg E, Plummer LN (1992) Use of chlorofluoromethanes $\left(\mathrm{CCl}_{3} \mathrm{~F}\right.$ and $\left.\mathrm{CCl}_{2} \mathrm{~F}_{2}\right)$ as hydrologic tracers and age-dating tools: example of the alluvium and terrace system of central Oklahoma. Water Resour Res 28:2257-2283

Busenberg E, Plummer LN (2000) Dating young ground water with sulfur hexafluoride: natural and anthropogenic sources of $\mathrm{SF}_{6}$. Water Resour Res 36:3011-3030

Busenberg E, Weeks E, Plummer LN, Bartholemay RC (1993) Age dating groundwater by use of chlorofluorocarbons $\left(\mathrm{CCl}_{3} \mathrm{~F}\right.$ and $\left.\mathrm{CCl}_{2} \mathrm{~F}_{2}\right)$, and disbribution of chlorofluorocarbons in the unsaturated zone, Snake River Plain aquifer, Idaho National Engineering Laboratory, Idaho: U.S. Geological Survey Water Resources Investigations Report 93-4054, USGS, 47 p

Cook PG, Böhlke JK (1999) Determining timescales for groundwater flow and solute transport. In: Cook PG, Herczeg AL (eds) Environmental tracers in subsurface hydrology, Kluwer, Boston, pp. $1-30$

Cook PG, Solomon DK, Plummer LN, Busenberg E, Schiff SL (1995) Chlorofluorocarbons as tracers of groundwater transport processes in a shallow, silty sand aquifer. Water Resour Res 31:425-434

Deines P (1980) The isotopic composition of reduced organic carbon. In: Fritz P, Fontes JCh (eds) Handbook of environmental geochemistry, Elsevier, New York 1:239-406

Dincer T, Payne BR (1971) An environmental isotope study of the southwestern karst region of Turkey. J Hydrol 14:233258

Dunkle SA, Plummer LN, Busenberg E, Phillips PJ, Denver JM, Hamilton PA, Michel RL, Coplen TB (1993) Chlorofluorocarbons $\left(\mathrm{CC}_{3} \mathrm{~F}\right.$ and $\left.\mathrm{CC}_{2} \mathrm{~F}_{2}\right)$ as dating tools and hydrologic tracers in shallow ground water of the Delmarva Peninsula, Atlantic Coastal Plain, USA. Water Resour Res 12:3837-3860 
Ekwurzel B, Schlosser P, Smethie WM, Jr, Plummer LN, Busenberg E, Michel RL, Weppernig R, Stute M (1994) Dating of shallow groundwater: comparison of the transient tracers ${ }^{3} \mathrm{H} /{ }^{3} \mathrm{He}$, chlorofluorocarbons, and ${ }^{85} \mathrm{Kr}$. Water Resour Res 30:16931708

Florida Springs Task Force (2000) Florida's springs: strategies for protection and restoration, Florida Springs Task Force, Tallahassee, FL, 57 p

Focazio MJ, Plummer LN, Böhlke JK, Busenberg E, Bachman LJ, Powars DS (1998) Preliminary estimates of residence times and apparent ages of groundwater in the Chesapeake Bay Watershed, and water-quality data from a survey of springs. U.S. Geological Survey Water-Resources Investigations Report 97-4225, 75 p

Fontes JC, Garnier JM (1979) Determination of the initial ${ }^{4} \mathrm{C}$ activity of the total dissolved carbon: a review of the existing models and a new approach. Water Resour Res 15:399_ 413

Heaton THE, Vogel JC (1981) Excess air in groundwater. J Hydrol 50:201-216

Ingerson E, Pearson FJ, Jr (1964) Estimation of age and rate of movement of groundwater by the ${ }^{14} \mathrm{C}$ method, in recent research in the fields of atmosphere, hydrosphere, and nuclear geochemistry, Sugawara Festival Volume, Maruzen, Tokyo, p. 263283

Katz BG (1992) Hydrochemistry of the Upper Floridan aquifer in Florida. U.S. Geological Survey Water Resources Investigations Report 91-4196, USGS, 37 pp

Katz BG, Lee TM, Plummer LN, Busenberg E (1995a) Chemical evolution of groundwater near a sinkhole lake, northern Florida: 1. Flow patterns, age of groundwater, and influence of lakewater leakage. Water Resour Res 31:1549-1564

Katz BG, Plummer LN, Busenberg E, Revesz KM, Jones BF, Lee TM (1995b) Chemical evolution of groundwater near a sinkhole lake, northern Florida. 2. Chemical patterns, mass-transfer modeling, and rates of chemical reactions. Water Resour Res 31:15651584

Katz BG, Hornsby HD, Böhlke JK, Mokray MF (1999) Sources and chronology of nitrate contamination in spring waters, Suwannee River Basin, Florida. U.S. Geological Survey Water-Resources Investigations Report 99-4252, 54 p

Katz BG, Böhlke JK, Hornsby HD (2001) Timescales of nitrate contamination of spring waters, northern Florida, USA. Chem Geol 179:167-186

Katz BG, Chelette AR, Pratt TR (2004) Use of chemical and isotopic tracers to assess nitrate contamination and ground water age, Woodville Karst Plain, USA. J Hydrol 289:3661

Katz BG (2004) Sources of nitrate contamination and age of water in large karstic springs of Florida. Environ Geol 46:689706

Knowles L, Jr, O’Reilly AM, Adamski JC (2002) Hydrogeology and simulated effects of ground-water withdrawals from the Floridan aquifer system in Lake County and in the Ocala National Forest and vicinity, north-central Florida. U.S. Geological Survey Water Resources Investigations Report 02-4207, $140 \mathrm{p}$

Ludin A, Weppernig R, Bonisch G, Schlosser P (1998) Mass spectrometric measurement of helium isotopes and tritium. Technical Report 98-06, Lamont-Doherty Earth Observatory, Palisades, NY

Manga M (2001) Using springs to study groundwater flow and active geologic processes. Annl Rev Earth Planet Sci 29:201228

Maloszewski P, Zuber A (1982) Determining the turnover time of groundwater systems with the aid of environmental tracers. 1. Models and their applicability. J Hydrol 57:207-231

Maloszewski P, Zuber A (1996) Lumped parameter models for the interpretation of environmental tracer data. In: Manual on mathematical models in isotope hydrology, IAEA-TECDOC 910, IAEA, Vienna, pp 9-50

Michel RM (1989) Tritium deposition in the continental United States 1953-1983. U.S. Geological Survey Water Resources Investigations Report 89-4072, $46 \mathrm{p}$
Miller JA (1982a) Configuration of the base of the upper permeable zone of the Tertiary limestone aquifer system, southeastern United States. U. S. Geological Survey Water-Resources Investigations Open-File Report 81-1177

Miller JA (1982b) Thickness of the upper permeable zone of the Tertiary limestone aquifer system, southeastern United States. U. S. Geological Survey Water-Resources Investigations OpenFile Report 81-1179, 1p

Miller JA (1986) Hydrogeologic framework of the Floridan aquifer system in Florida and in parts of Georgia, Alabama, and South Carolina. U. S. Geological Survey Professional Paper 1403-B, $91 \mathrm{p}$

Murray LC, Halford KJ (1996) Hydrogeologic conditions and simulation of ground-water flow in the greater Orlando metropolitan area, east-central Florida. U.S. Geological Survey WaterResources Investigations Report 96-4181, $100 \mathrm{p}$

O'Reilly AM, Spechler RM (2002) Hydrogeology and Water-Quality Characteristics of the Lower Floridan Aquifer in East-Central Florida. Water Resources Investigations Report 02-4193, 60 p

Osburn WL, Toth DJ, Boniol D (2002) Springs of the St. Johns River Water Management District. Technical publication SJ2002-5. St. Johns River Water Management District, Palatka, FL (CDROM)

Osburn WL (2001) Relationship between discharge at Blue Spring, Volusia County, and nearby springs. Memo, St. Johns River Water Management District, Palatka, FL

Ozyurt NN, Bayari CS (2003) LUMPED: a Visual Basic code of lumped parameter models for mean residence time analyses of groundwater systems. Comp Geosci 29:79-90

Phelps GG (2001) Geochemistry and origins of mineralized waters in the Floridan aquifer system, northeastern Florida. U.S. Geological Survey Water-Resources Investigations Report 01-4112, $64 \mathrm{p}$

Plummer LN (1993) Stable isotope enrichment in paleowaters of the southeast Atlantic Coastal Plain, United States. Science 262:2016-2020

Plummer LN, Prestemon EC, Parkhurst D (1994) An interactive code (NETPATH) for modeling net geochemical reactions along a flow path: Version 2.0. U. S. Geological Survey Water-Resources Investigations Report 94-4169, $130 \mathrm{p}$

Plummer LN, Busenberg E, McConnell JB, Drenkard S, Schlosser P, Michel RL (1998) Flow of river water into a karstic limestone aquifer. 1. Tracing the young fraction in groundwater mixtures in the Upper Floridan aquifer near Valdosta, Georgia. Appl Geochem 13:995-1015

Plummer LN, Busenberg E (1999) Chlorofluorocarbons, In: Cook PG, Herczeg A (eds) Environmental tracers in subsurface hydrology, Kluwer, Dordrecht, Chapt. 15, pp. 441-478

Plummer LN, Rupert MG, Busenberg E, Schlosser P (2000) Age of irrigation water in ground water from the eastern Snake River Plain aquifer, south-central Idaho. Ground Water 38:264-283

Plummer LN, Busenberg E, Bohlke JK, Nelms DL, Michel RL, Schlosser P (2001) Groundwater residence times in Shenandoah National Park, Blue Ridge Mountains, Virginia, USA: a multitracer approach. Chem Geol 179:93-111

Plummer LN, Sprinkle CL (2001) Radiocarbon dating of dissolved inorganic carbon in groundwater from confined parts of the Upper Floridan aquifer, Florida, USA. Hydrogeol J 9:127-150

Pollock DW (1994) User's guide for MODPATH/MODPATH-PLOT, version 3: a particle tracking post-processing package for MODFLOW, the U.S. Geological Survey finite-difference groundwater flow model. U.S. Geological Survey Open-File Report 94-464

Puri HS, Vernon RO (1959) Summary of the geology of Florida and a guide to the classic exposures. Florida Geological Survey Special Publication 5, $255 \mathrm{p}$

Reilly TE, Plummer LN, Phillips PJ, Busenberg E (1994) The use of simulation and multiple environmental tracers to quantify groundwater flow in a shallow aquifer. Water Resour Res 30:421-433

Rosenau JC, Faulkner GL, Hendry CW, Jr, Hull RW (1977) Springs of Florida. Florida Bur Geol Bull No. 31, 461 p 
Schlosser P, Stute M, Dorr H, Sonntag C, Munnich KO (1988) Tritium $/{ }^{3} \mathrm{He}$ dating of shallow groundwater. Earth Planet Sci Lett 89:353-362

Schlosser P, Stute M, Sonntag C, Munnich KO (1989) Tritiogenic ${ }^{3} \mathrm{He}$ in shallow ground water. Earth Planet Sci Lett 94:245256

Scott TM, Means GH, Means RC, Meegan RP (2002) First magnitude springs of Florida. Florida Geological Survey Open File Report No. 85, Tallahassee, FL, $138 \mathrm{p}$

SJRWMD (2003) Internal database of St. Johns River Water Management District, Palatka, FL, accessed January 30

Solomon DK, Sudicky EA (1991) Tritium and helium-3 isotope ratios for direct estimation of spatial variations in groundwater recharge. Water Resour Res 27:2309-2319

Solomon DK, Cook PG (1999) ${ }^{3} \mathrm{H}$ and ${ }^{3} \mathrm{He}$. In: Cook P, Herczeg A (eds) Environmental tracers in subsurface hydrology. Kluwer, Dordrecht, pp. 397-424

Spechler RM, Halford KJ (2001) Hydrogeology, water quality, and simulated effects of ground-water withdrawals from the Floridan Aquifer System, Seminole County and vicinity, Florida. U.S. Geological Survey Water-Resources Investigations Report 014182, $116 \mathrm{p}$

Stringfield VT (1966) Artesian water in Tertiary limestone in the southeastern States. U. S. Geological Survey Professional Paper $517,226 \mathrm{p}$

Tamers MA (1975) Validity of radiocarbon dates on groundwater. Geophys Surv 2:217-239

Thatcher LL (1962) The distribution of tritium fallout in precipitation over North America. Bull Int Assoc Hydrol Sci 7:48-58
Tibbals CH (1990) Hydrology of the Floridan Aquifer System in East-Central Florida: U.S. Geological Survey Professional Paper 1403-E, $98 \mathrm{p}$

Torgersen T, Clarke WB, Jenkins WJ (1979) The tritium/helium-3 method in hydrology. In: Isotope hydrology 1978, IAEA, Vienna, pp 917-929

Toth DJ (1995) Groundwater recharge rates calculated from the isotopic content of groundwater: a pilot study. St. Johns River Water Management District, Technical Publication SJ95-3, Palatka, FL

Toth DJ (1999) Water quality and isotope concentrations from selected springs in the St. Johns River Water Management District, Technical Publication SJ99-2, St. Johns River Water Management District, Palatka, FL, $67 \mathrm{p}$

Weise S, Eichinger L, Forster M, Salvamoser J (1992) Helium-3 and krypton-85 dating of shallow groundwaters: diffusive loss and correlated problems. In: Isotopes of noble gases as tracers in environmental studies, International Atomic Energy Agency Panel Proceedings Series, IAEA, Vienna, pp. 147-162

Zuber A (1986) Mathematical models for the interpretation of environmental radioisotopes in groundwater systems, In: Fritz P, Fontes JCh (eds) Handbook of environmental geochemistry: the terrestrial environment, Elsevier, New York 2:1-59

Zuber A, Michalczyk Z, Maloszewski P (2001) Great tritium ages explain the occurrence of good-quality groundwater in a phreatic aquifer of an urban area, Lublin, Poland. Hydrogeol J 9:451460 